\title{
Is Islamic Banking Good for Growth?
}

\author{
PATrick Imam \\ KANGNi KPODAR
}

C Pатвіск Iмам is a Senior Economist in the African Department at the International Monetary Fund (IMF).

KANGni Kpodar is a Senior Economist in the Fiscal Affairs Department at the IMF and Associate Fellow at Ferdi.

\section{Abstract}

The rapid growth of Islamic banking has attracted much attention lately in the economic literature. At the same time, a mature body of the literature has shown that financial development is broadly conducive to economic growth, which raises the question as to whether a similar conclusion holds for Islamic banking. Against this backdrop, this paper investigates the relationship between Islamic banking development and economic growth in a sample of low and middle income countries, using data over the period 1990-2010. The results show that, notwithstanding its relatively small size compared to the economy and the overall size of the financial system, Islamic banking is positively associated with economic growth even after controlling for various determinants, including the level of financial depth. The results are robust across across different specifications, sample composition and time periods.

Keywords: Keywords: Islamic banking, financial development, economic growth.

JEL Classification: Go, G21, O10

The authors are very grateful to Maher Hassan, Sylviane Guillaumont Jeanneney, Sami Ben Naceur, Doris Ross and Zeine Zeidane for constructive comments and suggestions. Graham Colin-Jones provided useful editorial assistance.

The views expressed in this Working Paper are those of the authors and do not necessarily represent those of the IMF or Ferdi. 


\section{Summary}

\section{Contents}

Page

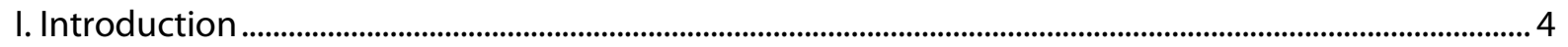

II. Literature Review ….................................................................................................................................

III. Econometric Estimation ..............................................................................................................................

A. The data and model

B. The methodology

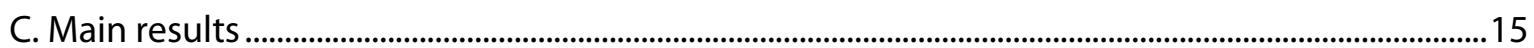

IV. Conclusion

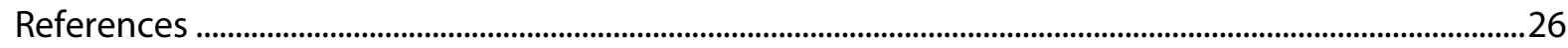

\section{Tables}

1. Islamic Banking and Growth: Pooling and Fixed Effect Regressions .......................................................16

2. Islamic Banking and Growth: Dynamic Panel System GMM estimations..............................................19

3. Dynamic Panel System GMM Estimations with Alternative Indicators of Islamic Banking

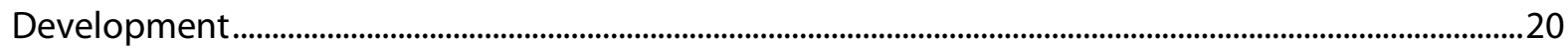

4. Use of Different Indicators of Overall Financial Development (System GMM Estimations) ............21

5. Sensitivity to Sample Composition (System GMM Estimations)............................................................23

6. Sensitivity to Time Periods (System GMM Estimations) ............................................................................24 


\section{Figures}

1. Average GDP per Capita in Islamic and Other Countries (1990-2010) ....................................................... 5

2. Average Real GDP Growth: How do Islamic Countries Compare to Others (1990-2010)? .................. 6

3. Average Private Sector Credit Ratio to GDP in Islamic and Other Countries (1990-2010) ................. 6

4. Islamic Banking Development and Economic Growth (1990-2010) ......................................................14

\section{Annex}

1. Islamic Banking and Growth: Dynamic Panel System GMM estimations with Standardized

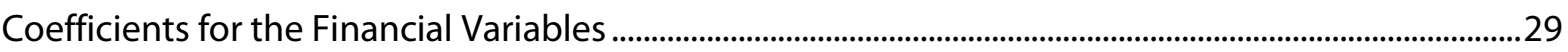

\section{Appendix Tables}

1. Variable Definition and Sources ....................................................................................................................

2. Correlation Matrix

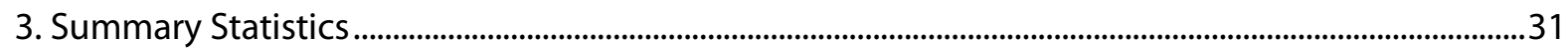

4. Country Sample 


\section{INTRODUCTION}

Since the modern birth of Islamic banking in the 1970s in Egypt, it has expanded rapidly across the globe. As illustrated by Imam and Kpodar (2013), such expansion has taken place, in particularthough not exclusively -in countries with larger Muslim populations. From an insignificant beginning, the industry has grown to over USD 1.6 trillion in assets in 2012, and is expected to reach USD 6.1 trillion by the end of this decade (Gewal, 2013). Not only have local banks in Muslim countries adopted Islamic banking principles, but large multinational banks have established Islamic windows. Islamic finance has spread beyond commercial banks, and now spans investment banks, insurance companies, as well as investment (e.g. asset management) and financial companies (e.g. leasing). The development of new products, such as sukuks (Islamic bonds), has also broadened the range of products available.

There is mounting evidence-at least for lower and middle income countries-that financial sector development is good for growth (see for instance the seminal paper of Levine, Loayza, and Beck, 2000). A developed financial sector helps mobilize savings, facilitates the allocation of capital to where returns are expected to be highest, monitors the use of capital once invested, and allows for diversification of risk. Moreover, there is a growing consensus among economists that it does not matter much for economic growth whether the financial system is more bank-based or marketbased (Allen and Gale, 2000; Levine, 2002). The particular institutional arrangements that provide financial services to the economy are not so important; what matters is the level of overall financial development.

However, do these findings of financial sector deepening impacting growth also apply to systems where Islamic banking plays a significant role? This is an important question to answer, as with a few exceptions, countries with large Islamic populations are typically not highly developed (see Figure 1), and have often not performed well in economic terms, one of the reasons being an underdeveloped financial system. 
Figure 1. Average GDP per Capita in Islamic and Other Countries (1990-2010)

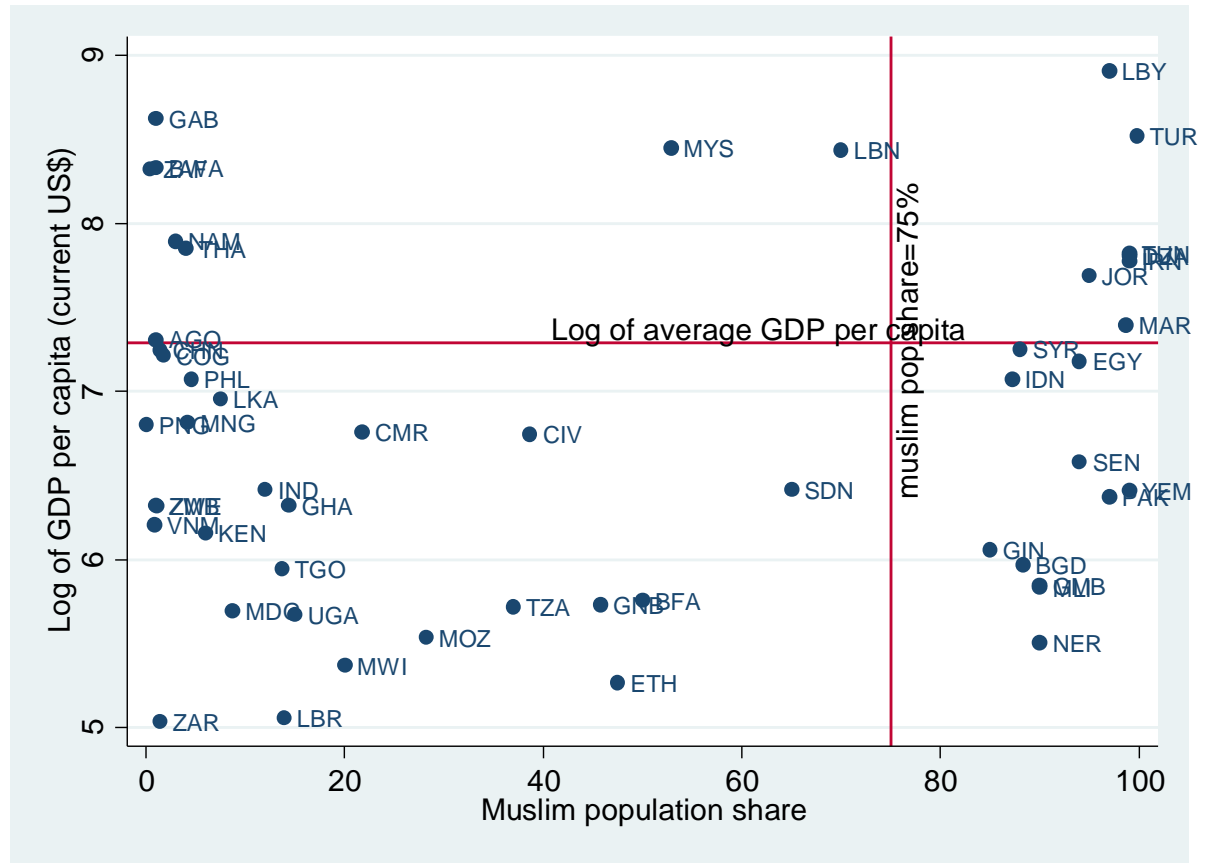

Sources: IMF, Alesina, et al. (2003)

Note: See Appendix table 4 for country names.

Growth in Islamic countries, while not spectacular, has not been dismal compared to other countries with a similar level of development. The widely held perception is that Islamic countries have performed poorly in economic terms since the 1950s, but this does not hold. After an initial strong growth spurt following independence-in sync with other low-income countries (LICs) growth rates were sub-par following the lost decades of the 1980s and 1990s. While it is true that Islamic countries and sub-national regions with large Muslim populations are characterized by low incomes and a low level of social development, with the exception of oil-producing Gulf countries, they are in fact not much different from other emerging markets (EMs) and LICs (Figure 2). In fact, once adjustments for low education levels, poor institutions, commodity prices, etc., are made, evidence is mounting that Islam per se is not holding back these countries (Nolan, 2003). 
Figure 2. Average Real GDP Growth: How do Islamic Countries Compare to Others (1990-2010)?

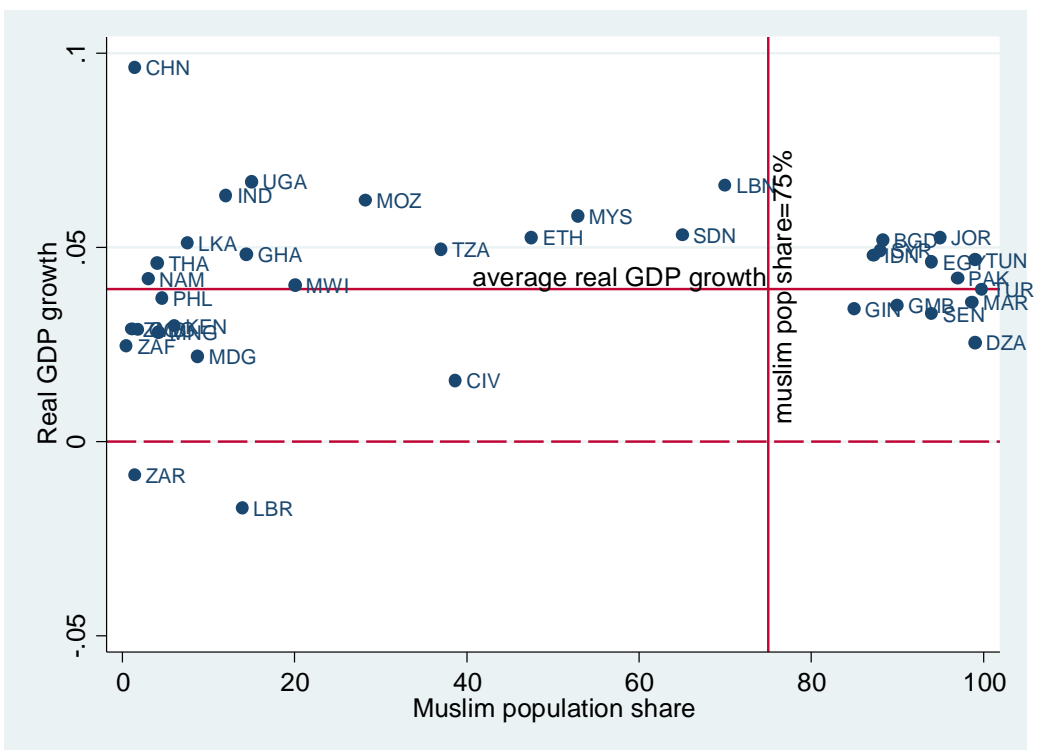

Sources: IMF, Alesina, et al. (2003)

Note: See Appendix table 4 for country names.

Similarly, Islamic countries do not currently stand out in terms of private sector credit to GDP (Figure 3). However, as Islamic banking becomes more acceptable to a large swath of the population, it could expand faster, as it would not necessarily be a substitute for conventional banking, but it would provide financial products to a part of the population that otherwise would not use the financial system, potentially leading to higher financial inclusion and an acceleration of economic growth in these countries.

Figure 3. Average Private Sector Credit Ratio to GDP in Islamic and Other Countries (1990-2010)

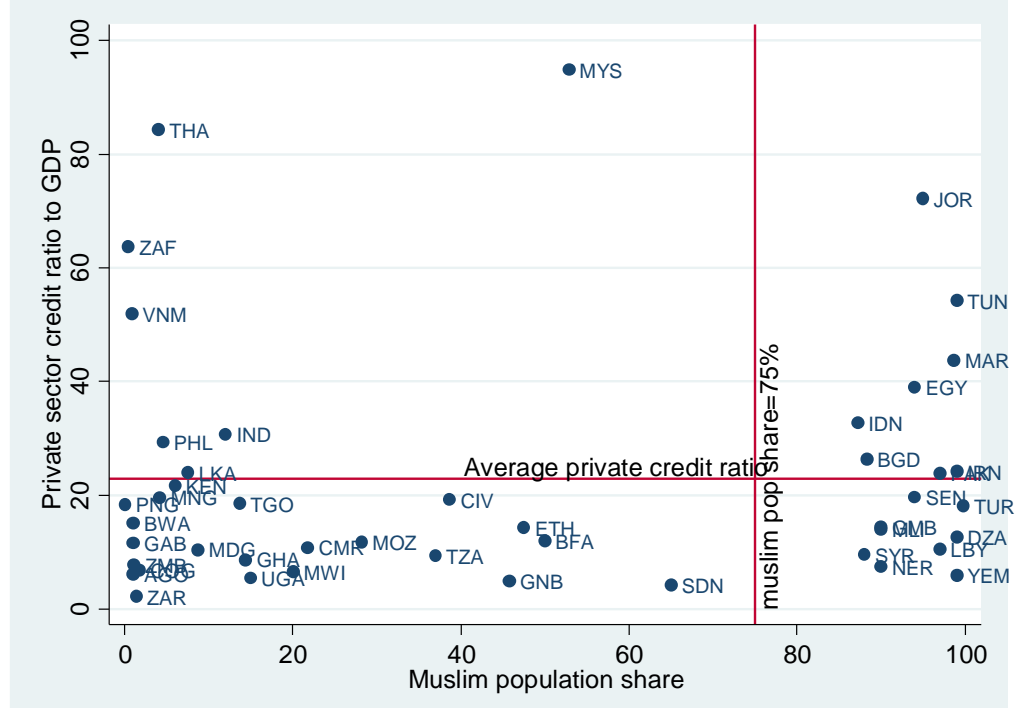

Sources: Beck, Demirguc-Kunt and Levine, (2000), Alesina, et al. (2003)

Note: See Appendix table 4 for country names. 
Thus, the rapid diffusion of Islamic banking represents a growth opportunity for Islamic countries, as much of the empirical evidence suggests a strong link between financial sector development and growth (see Levine (2005) for a summary). However, the empirical literature has only looked at conventional banking, not Islamic banking. This paper aims to rectify this lacuna, by considering whether Islamic banking is also potent in raising growth. Using a sample of low- and middleincome countries with data over the period 1990-2010, we investigate the impact of Islamic banking on growth and discuss the policy implications. The results show that, notwithstanding its relatively small size compared to the economy or the overall size of the financial system, Islamic banking is positively associated with economic growth even after controlling for various determinants, including the level of financial depth. The results are robust across different measures of Islamic banking development, econometric estimators (pooling, fixed effects and System GMM), and to the sample composition and time periods.

The paper is structured as follows. Section II reviews the literature, with a focus on how Islamic banking could help financial deepening, and ultimately growth. Section III presents the sample, the econometric model, and estimators, as well as the results. Section IV concludes with the policy implications.

\section{Literature ReVIEW}

Although the finance-growth nexus continues to be heavily debated in the literature, the main thrust is that financial development has, by and large, a favourable impact on economic growth. Financial intermediaries carry out five basic functions that serve growth: they (i) facilitate the trading, hedging, diversifying, and pooling of risk; (ii) allocate resources; (iii) monitor managers and exert corporate control; (iv) mobilize savings; and ( $v$ ) facilitate the exchange of goods and services (see Levine, 1997). In performing their functions, financial intermediaries mitigate the effects of information and transaction costs, and improve the allocation of resources, thus influencing saving rates, investment decisions, technical innovation, and ultimately long-run growth rates. In turn, economic activity can also influence financial development. It is worth noting that this whole literature implicitly refers to conventional banking. An interesting question is: does this also apply to Islamic banks?

The literature has evolved overtime, however, and depicted alternating periods of optimism and scepticism on the benefits of finance for growth. It began early with the work of Schumpeter (1912), who highlighted the essential role of banks in financing innovative businesses and increasing productivity. Robinson (1952) challenges this view, arguing that financial development simply follows economic growth. Although Gurley and Shaw (1960) share Schumpeter's view on the importance of finance for growth, they stress instead the role of financial innovation for economic development, as it facilitates better risk management and a reduction in intermediation costs. 
However, following the work of McKinnon (1973) and Shaw (1973), mixed country experiences from the wave of financial liberalization policies in the 1970s and 1980s raised uncertainties on the potential benefits of finance for growth. The studies of King and Levine (1993a, 1993b and 1993c) and Levine (1997) gave a new impetus to the finance-growth literature. The authors thoroughly documented the channels through which financial development positively impacted economic growth and undertook convincing theoretical and empirical investigation to support their hypothesis. Subsequent studies confirmed their findings (e.g. Rajan and Zingales, 1998; Levine, Loayza, and Beck, 2000), although some more recent studies-especially since the global financial crisis--cast doubt on the strength of the positive relationship between financial development and growth (see for instance Andersen and Tarp, 2003, Arcand, Berkes and Panizza, 2012 and Panizza, 2014). There is also evidence that by increasing the likelihood of banking crisis, the positive relationship between financial sector development and growth may be conditional (see Guillaumont Jeanneney and Kpodar, 2006).

Following the Miller and Modigliani (1958) capital structure irrelevance theory, it is likely that Islamic banking and conventional banking will not have different impacts on growth per se, if they finance the same projects. Although the benefits/risks of the project are distributed differently for conventional banks than for Islamic banks, the overall return on the project is the same. On the other hand, while Islamic banks perform similar functions to conventional banks, they have distinct features. In fact, Islamic banking has many advantages, not only in Islamic countries, but also in low- and middle-income countries in general, that could explain why it is preferable in stimulating growth to conventional banking, under certain circumstances. What are these distinct advantages of Islamic banking?

- Encourages lending (to individuals without assets). Conventional banks in most countries lend based on some form of guarantee/collateral. The risk-sharing characteristic of Islamic banking means that the borrower and the bank share the risk of any investment on agreed terms, and divide any profits or losses between them, without recourse to guarantees. Risk-sharing leads providers of financial capital and entrepreneurs to share business risks in return for a share of profits, suggesting that borrower liabilities are state-contingent, in contrast to conventional banks. This should in principle encourage more investment-notably by individuals who could not otherwise borrow because of a lack of assets that could act as a guarantee-and thereby investment. ${ }^{1}$ Through the prohibition of riba (interest rates), the incentives of lenders and

1 Most Islamic financial instruments can be thought of as falling into one of two general families. First, contracts can be classified as venture financing, where the provider of funds to a venture expects a return conditional on the success of the venture (profit-and-loss sharing, PLS). Contracts that are most common include equitable participation (musharaka) in a venture such as an import consignment and a sleeping partnership (mudaraba) in a defined venture. Second, and rising in importance are payment smoothing arrangements, where an intermediary's client has a lumpy cash need in order to accomplish some project (e.g. housing, productive investment). The intermediary enters into an arrangement which, while profitable to it, enables the client to smooth their cash outlay. For example, the provider of funds may acquire a productive asset and make it available to the user of funds for a fee, as in installment sale (murabaha), leasing (ijarah) or hire-purchase arrangements (see Honohan, 2001). These innovations should help economic development in Islamic countries, by providing access to financing that is acceptable to the (pious) population. 
borrowers are aligned, thus reducing moral hazard. At the same time, it helps to spur investment that would otherwise not take place, and thereby growth, and also acts as a shock absorber for countries subject to large shocks.

- Raises savings. Islamic banking can raise the savings of pious individuals who refrain from using conventional banks, as they do not satisfy the needs of devout Muslims, who are not willing to put their savings into a financial system that is not based on religious principles. This could thereby increase financial intermediation. Demirguc-Kunt et al. (2013) explore the difference between Muslims and non-Muslims within the same country, and find that in the 64 countries they cover, 24 percent of Muslim adults report having a bank account, in contrast to 44 percent of non-Muslims who have one. This under-banking of an important segment of the population leads to savings not being channeled to the formal sector, and therefore not being used efficiently, leading to sub-optimal financial intermediation. ${ }^{2}$ Bringing Muslims into the formal sector, by providing them with suitable products, would increase access to finance, with savings increasing commensurately.

- Enhances financial stability. Most boom-bust cycles witnessed across the world in recent decades have exposed several underlying factors that highlight the vulnerability of conventional banking, namely high leveraging, wholesale financing, and utilization of complex instruments. ${ }^{3}$ In Islamic finance, balance sheet mismatches are absent, as banks do not have asset-liability mismatches, given that short-term deposits finance short-term trading, while for longer-term investments, longer-term deposits are used (Mirakhor, 2010). There is also consistent evidence of higher capitalization of Islamic banks, and this capital cushion combined with higher liquidity reserves explains the relatively better performance of Islamic banks during the recent crisis. Derivatives and other non-transparent products are also disallowed. This, combined with the sharing of profits and losses, creates a less crisis prone system (Cihak and Hesse, 2008; Hassan and Dridi, 2010). It is probably fair to say that banking systems that are diversified, through including Islamic banks as a complement to conventional banks, are likely to contribute to financial stability (Imam and Kpodar, 2013). ${ }^{4}$

- Finances morally acceptable projects. Islamic banking is based on a moral system of Islam, which only allows for the financing of assets that are not harmful to society. Islamic banks are not allowed to finance casinos and other activities that tend to be harmful to society, and the poor in particular. This aspect is difficult to quantify, but could be growth enhancing by reducing negative externalities imposed on society by undesirable projects. If conventional banking and

\footnotetext{
2 Growing evidence (see Demirguc-Kunt and Levine, 2009) suggests that better functioning financial systems exerts a disproportionately positive impact on the relatively poor.

3 Islamic banking prohibits speculative products, which are deemed 'gharar'-contracts and transactions that contain excessive uncertainty. This reduces the probability of fraud, for instance. Derivative products are generally viewed as unacceptable under Shariah, as they involve speculation.

4 Minsky moments, whereby periods of calm create the seeds for financial instability (endogenous financial instability) are absent in Islamic banking.
} 
Islamic banking co-exist, this aspect is unlikely to matter much, as 'haram' activities can be financed by conventional banking.

All these factors are, in principle, conducive to higher growth and poverty alleviation. Moreover, if Islamic banking is more likely to develop in Islamic countries because it is more acceptable to pious Muslims, growth is likely to accelerate more rapidly in these countries than it would if only conventional banking were available. However, Islamic banks have certain structural weaknesses that counterbalance the positive aspects:

- Lack of Economies of Scale. Islamic banks are often newer, and therefore smaller, than conventional banks. This means that they are often still below optimal scales and thus have higher cost structures (Hasan and Dridi, 2010). ${ }^{5}$ We should expect that, with continued growth, the disadvantage of scale will disappear over time as the industry grows. Comparing conventional and Islamic banks and controlling for other bank and country characteristics, Beck et al. (2010) find few significant differences in business orientation, efficiency, asset quality, or stability. While Islamic banks seem more cost-effective than conventional banks in a broad cross-country sample, this finding reverses in a sample of countries with both Islamic and conventional banks. However, conventional banks that operate in countries with a higher market share of Islamic banks are more cost-effective but less stable.

- Lack of Liquid Instruments. There is no secondary market for Islamic fixed-income products, forcing Islamic banks to have large liquidity buffers, putting them at a disadvantage relative to conventional banks (Moody's, 2009). This is because Islamic banks are prohibited from engaging in activities that include interest, but the way central banks function is through a repo that includes interest bearing assets. The establishment in 2010 of the "International Islamic Liquidity Management Corporation" (IILM), whose objective is to issue Shariah-compliant financial instruments that facilitate more efficient and effective liquidity management solutions for institutions offering Islamic financial services, should help address this problem. ${ }^{6}$ However, this is still a work in progress.

Thus, Islamic banks have features that can promote growth, but at the same time are disadvantaged by the lack of economies of scale and liquid instruments-though work is ongoing to address these shortcomings. This suggests that the answer to the question as to whether Islamic

\footnotetext{
5 Smallness of the financial system has obvious, though not necessarily visible, costs to the macro-economy. In the academic literature, micro-studies such as Rajan and Zingales (1998) and macro-level studies such as Levine (2005) have illustrated the causality of financial sector development on economic growth. A small financial system implies a lack of economies of scale, as there are significant fixed costs in setting up operations. As more individuals and firms use financial intermediaries, the information flow on customers improves, but a small financial system reduces the information flow function of financial intermediaries (Greenwood and Jovanovic, 1990). Smallness of the financial system also suggests limited risk-diversification options for savers and investors alike. In addition, a small financial system implies that profitable investment opportunities will be forgone, thereby limiting growth below potential. However, the lack of easily available financing increases the resilience of the economy to shocks, smoothing consumption over time-a feature particularly important for many LICs/EMs that lack flexibility.

6 http://www.ifsb.org/preess full.php?id=149\&submit=more
} 
banking promotes growth lies in the empirical evidence. While there is a plethora of empirical studies on the impact of financial development on growth, ${ }^{7}$ studies on how Islamic banking development affects growth are nonexistent, a void this paper attempts to fill in the next section.

\section{ECONOMETRIC ESTIMATION}

\section{A. The data and model}

In this section, we empirically attempt to assess the impact of Islamic banking on growth. We construct a panel of 52 developing economies, of which 29 belong to the Organization of Islamic Countries (OIC), with data spanning the period 1990-2010, and averaged over 3-year intervals. The sample size is constrained by data availability, in particular on variables capturing Islamic banking expansion and the quality of the institutional environment. In addition, we restricted the sample to low and middle income countries as the macroeconomic variables included in the growth model are more relevant to them, and also because this helps reduce sample heterogeneity. With regard to the length of the time period, the 3-year average represents a good balance between the need to smooth business cycle fluctuations and that of ensuring an adequate number of observations for the regressions.

We rely on a standard growth model, with a set of variables of interest measuring broad financial development and Islamic banking development, and control variables conventionally utilized in the growth literature. The data sources for the variables are found in Appendix Table 1. The variables of interest consist of:

- Development of Islamic banking. As discussed above, there are theoretical grounds for expecting a positive impact of Islamic banking development on growth. This makes Islamic banking indicators good candidates for explaining cross-country growth. We measure Islamic banking development by the amount of loans extended by these banks to the private sector divided by nominal GDP. While this indicator gives an idea on the size of the Islamic banking sector, it may not accurately measure the indirect channels through which Islamic banks could ignite growth (facilitate risk sharing, enhance financial stability, and mobilize savings). However, it is reasonable to assume that the larger the Islamic banking sector, the better it can perform its functions, a common hypothesis also made for conventional banking in past studies. We also use two alternative indicators of Islamic banking development: the ratio of Islamic banking assets to GDP and the ratio of deposits in Islamic banks to GDP, the latter being a useful indicator to gauge the ability of Islamic banks to mobilize savings. ${ }^{8}$ As a robustness check we also used an indicator of capitalization (the capital-to-asset ratio), and the standard ratios of

\footnotetext{
7 Levine (2005) offers an overview of empirical studies on financial development and growth. For a more recent survey, see Panizza (2014).

8 The lack of data availability prevents us from considering Islamic bond ("sukuk") market development. The market is still in its infancy and has low volumes.
} 
Return on Equity (ROE) and Return on Assets (ROA) to measure the financial strength and profitability of Islamic banks.

- Development of the overall banking system. There is a general acceptance in the economic literature that financial deepening stimulates growth (for a literature review, see Levine, 2005 and 2007). As a result, we include in the model the ratio of private sector credit by commercial banks in percent of GDP as a measure of the development of the banking sector. Since both conventional and Islamic banking coexist in many countries and evolve together, it is important to control growth for the overall size of the banking system in order to properly isolate the growth impact of Islamic banking. Alternative measures of financial development considered include the ratio of private sector credit by bank and nonbank financial institutions in percent of GDP, the total assets of financial institutions as a ratio of GDP and finally the total financial system deposits as a ratio to GDP.

The control variables include:

- Initial real GDP per capita. This variable is intended to control for growth convergence as the neoclassical model points out that lower income countries, with lower initial levels of technology and capital, will tend to grow faster than more advanced countries.

- Inflation: It has long been argued that inflation uncertainty lowers real output growth. Inflation uncertainty increases the variability of prices, which distorts the price signal and thereby harms economic efficiency and productivity. In addition, high inflation is likely to be associated with weaker growth as it is often a reflection of weak quality and unsustainable macroeconomic policies.

- Government consumption. The issue of government spending and its effect on economic growth is still widely debated in the economic literature. While government spending is necessary, and has a growth-enhancing impact when it finances public goods such as infrastructure, it can deter growth when excessively dominated by current spending. The hypothesis is that rising government consumption (as a percent of GDP) encourages poor quality spending, leads to an oversized government and often results in a waste of public resources, which crowd out private investment when government relies on domestic resources to finance growing deficits.

- Education: Human capital accumulation, as proxied by the primary school enrolment rate, is expected to have a positive impact on growth through improved labor productivity.

- Trade Openness: It is to be expected that countries that are more open will experience higher economic growth, as they can take better advantage of economies of scale in production, benefit from technological transfer, promote efficient allocation of resources, and encourage competition in domestic markets. At the same time, trade openness can make countries more vulnerable to exogenous shocks when export concentration is high, making growth more volatile, which ultimately can result in lower long-term growth. 
- Terms of Trade: Improvements in terms of trade are often associated with economic growth. Conversely, deteriorating terms of trade would hamper growth, especially in developing countries where financial markets are shallow.

- Quality of Institutions: Institutional quality matters for long-term growth, as it determines the incentives of and the constraints on economic actors, fosters better policy choices, and shapes economic outcomes (Acemoglu, Johnson and Robinson, 2004). However, measuring accurately institutional development remains a challenge. While, no perfect or comprehensive indicator exists, we opted for the indicator of rule of law as a proxy for the quality of institutions, as compiled by the International Risk Country Guide (ICRG), which is widely used in the literature.

The baseline regression looks as follows:

$$
G_{i t}=\alpha+\beta \text { IslBank }_{\mathrm{it}}+\delta \mathrm{FD}_{\mathrm{it}}+\varphi X_{i t}+\mathrm{u}_{\mathrm{i}}+\varepsilon_{i t}+v_{t}
$$

where: $\mathrm{G}$ is the growth rate of real GDP per capita; IsIBank is the indicator of Islamic banking development (ratio of loans, assets, or deposits in Islamic banks to GDP); FD is the measure of overall financial development (ratio of private sector credit by commercial banks to GDP); $\mathrm{X}$ is the set of control variables described above; $u$ is the country-specific effect, $\varepsilon$ the error term and $v$ is the time-specific effect (see Appendix table 1 for the source and description of data).

\section{B. The methodology}

Estimating the growth impact of Islamic banking poses several econometric challenges. First, while Islamic banking is fast growing, the size of Islamic banking development in relation to GDP or banking assets is often zero, or very small in the majority of countries, including Islamic ones. This makes it challenging to identify any statistically significant impact. Second, like for conventional banking, there may be a reverse causality from growth to Islamic finance, raising an endogeneity issue that needs to be addressed in the regressions. Third, the indicators of Islamic bank development are subject to measurement errors as only pure Islamic banks are covered by statistics while Islamic windows (of conventional banks) are not included, due to lack of data. This is because conventional banks often do not separate in their balance sheets and financial reports activities related to Islamic finance from those of conventional banking. The underestimation of Islamic banking development would lead to a downward bias of the estimated coefficient.

In light of the challenges outlined above, we use a range of econometric techniques which include pooling and fixed effects estimator to control for country-specific effects, and the System GMM estimator to control for endogeneity bias. In the following section, we will provide the rationale behind each econometric estimator, as well as what issues they address and what they don't. Before that, we look at the two-way relationship between real GDP per capita growth and each of the three indicators of Islamic banking development. This simple illustration suggests a positive correlation between Islamic banking development and economic growth (Figure 4 and Appendix 
table 2). This result holds for the whole sample as well as for the sub-sample of countries with Islamic banks (Figure 4).

Figure 4. Islamic Banking Development and Economic Growth (1990-2010)

Ratio of Loans by Islamic Banks to GDP and Growth (Sample: All countries)

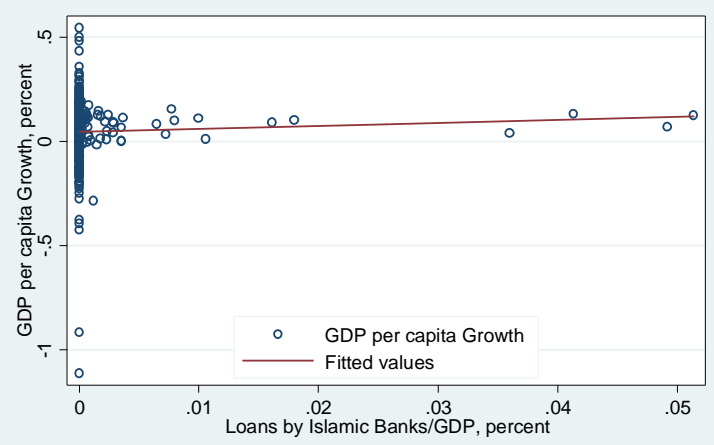

Ratio of Islamic Banks' Assets to GDP and Growth (Sample: All countries)

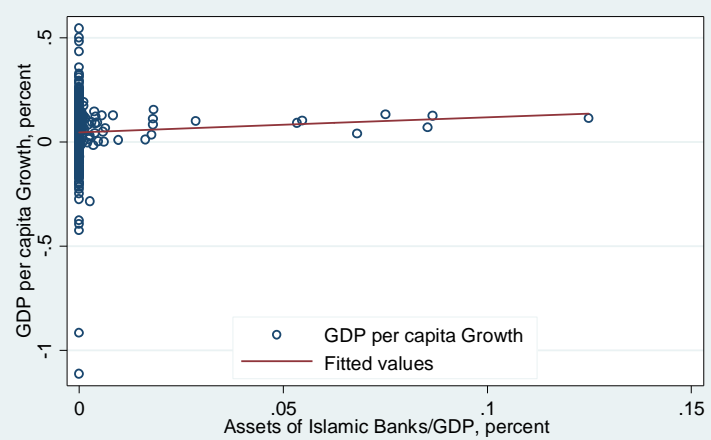

Ratio of Deposits in Islamic Banks to GDP and Growth (Sample: All countries)

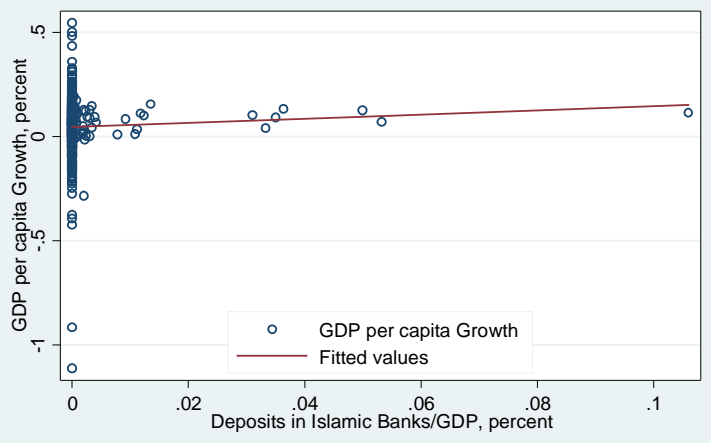

Ratio of Loans by Islamic Banks to GDP and Growth (Sample: Strictly positive values of islamic banking)

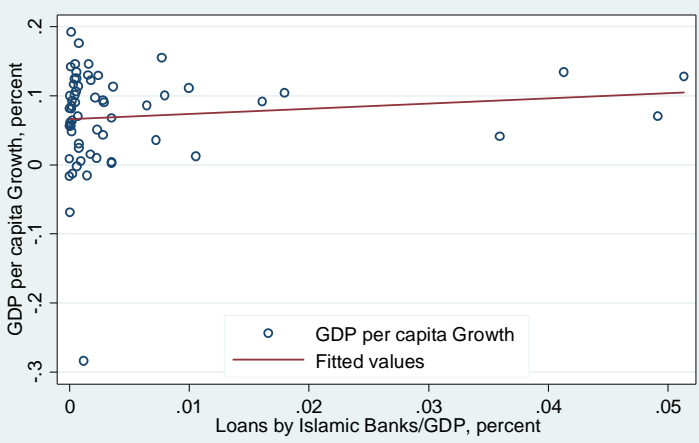

Ratio of Islamic Banks' Assets to GDP and Growth (Sample: Strictly positive values of islamic banking)

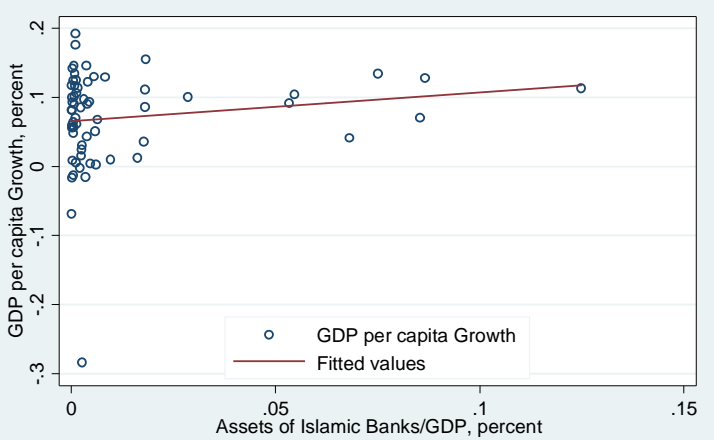

Ratio of Deposits in Islamic Banks to GDP and Growth (Sample: Strictly positive values of islamic banking)

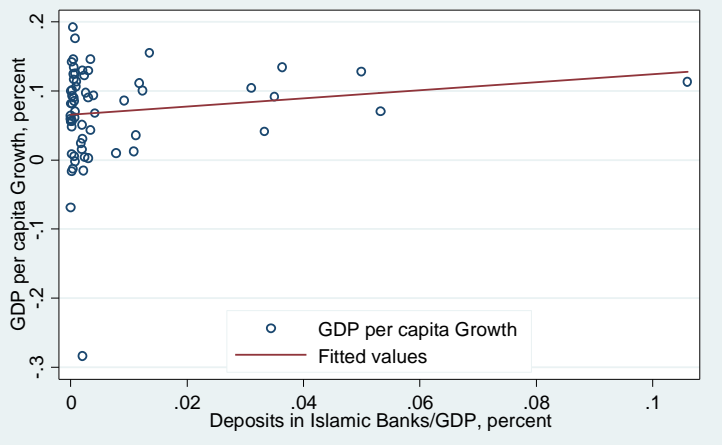

Notes: Data are 3-year average over the period 1990-2010

Sources: IMF, Bankscope, authors' calculations 


\section{Main results}

\section{Pooling and Fixed-effects}

Table 1 presents the results from the estimations using a pooling and fixed-effect estimator. The pooling estimator runs ordinary least squares (OLS) with the panel data, without regard to which countries they belong. Unlike the pooling estimator, a fixed-effect estimator allows to control for unobservable country-specific effects invariant over time, and which affect a country's economic growth. The results from the pooling estimation are presented in columns 1 to 6 , while those of the fixed-effect estimator are shown in columns 7 to 12. For each series of regressions, the first specification runs the baseline model only with the control variables (columns 1 and 7), while the second specification controls for overall financial development (columns 2 and 8 ) measured by the ratio of private sector credit by commercial banks in percent of GDP. Subsequent specifications (column 3 to 6,9 to 12) add in turn the 3 indicators of Islamic banking development, as well as a composite indicator constructed as the first principal component of the above 3 indicators of Islamic banking development using the principal component analysis (PCA).

The findings confirm the well-known result found in the economic literature that financial deepening matters for growth. The coefficient is positive and significant in all specifications at least at the 5 percent significance level. More interestingly, for a given level of financial development, Islamic banking is found to stimulate growth. The coefficients for all the indicators of Islamic banking development, including the composite index, are positive and enter the regressions in a statistically significant way, confirming the theoretical predictions, despite the fact that Islamic banking has been small relative to GDP. ${ }^{9}$ This result suggests that Islamic banking responds to the specific needs of households and firms, which would have been otherwise unmet and the associated incremental growth would have been forgone. This result also provides evidence that Islamic banking does not appear to crowd out traditional finance-it complements, rather than substitutes for conventional banking - as for a given level of financial development, more Islamic banking raises economic growth.

9 A cross-country regression averaging the dependant and explanatory variables over the entire period also shows that Islamic banking is positively and significantly correlated with economic growth. 


\begin{tabular}{|c|c|c|c|c|c|c|c|c|c|c|c|c|}
\hline & \multicolumn{6}{|l|}{ Pooling } & \multicolumn{6}{|c|}{ Fixed effects } \\
\hline & $(1)$ & $(2)$ & (3) & (4) & $(5)$ & (6) & (7) & $(8)$ & (9) & $(10)$ & (11) & (12) \\
\hline \multirow[t]{2}{*}{ Initial GDP per capita } & -0.001 & -0.012 & -0.013 & -0.014 & -0.014 & -0.014 & -0.034 & -0.102 & -0.110 & -0.102 & -0.101 & -0.102 \\
\hline & {$[0.005]$} & {$[0.006]^{*}$} & {$[0.006]^{* *}$} & {$[0.006]^{* *}$} & {$[0.006]^{* *}$} & {$[0.006]^{* *}$} & {$[0.034]$} & {$[0.037]^{* * *}$} & {$[0.039]^{* * *}$} & {$[0.037]^{* * *}$} & {$[0.037]^{* * *}$} & {$[0.037]^{* * *}$} \\
\hline \multirow[t]{2}{*}{ Education } & 0.062 & 0.059 & 0.060 & 0.062 & 0.062 & 0.061 & 0.153 & 0.165 & 0.171 & 0.167 & 0.166 & 0.167 \\
\hline & {$[0.020]^{* * *}$} & {$[0.019]^{* * *}$} & {$[0.019]^{* * *}$} & {$[0.019]^{* * *}$} & {$[0.019]^{* * *}$} & {$[0.019]^{* * *}$} & {$[0.049]^{* * *}$} & {$[0.048]^{* * *}$} & {$[0.048]^{* * *}$} & {$[0.048]^{* * *}$} & {$[0.048]^{* * *}$} & {$[0.048]^{* * *}$} \\
\hline \multirow[t]{2}{*}{ Inflation (log) } & -0.084 & -0.078 & -0.078 & -0.080 & -0.080 & -0.079 & -0.085 & -0.080 & -0.077 & -0.080 & -0.081 & -0.080 \\
\hline & {$[0.007]^{* * *}$} & {$[0.011]^{* * *}$} & {$[0.011]^{* * *}$} & {$[0.010]^{* * *}$} & {$[0.009]^{* * *}$} & {$[0.010]^{* * *}$} & {$[0.008]^{* * *}$} & {$[0.009]^{* * *}$} & {$[0.008]^{* * *}$} & {$[0.008]^{* * *}$} & {$[0.008]^{* * *}$} & {$[0.008]^{* * *}$} \\
\hline \multirow{2}{*}{ Government consumption/GDP } & -0.252 & -0.330 & -0.328 & -0.319 & -0.318 & -0.321 & -0.517 & -0.685 & -0.670 & -0.673 & -0.673 & -0.671 \\
\hline & {$[0.101]^{* *}$} & {$[0.117]^{* * *}$} & {$[0.118]^{* * *}$} & {$[0.118]^{* * *}$} & {$[0.118]^{* * *}$} & {$[0.118]^{* * *}$} & {$[0.218]^{* *}$} & {$[0.242]^{* * *}$} & {$[0.242]^{* * *}$} & {$[0.241]^{* * *}$} & {$[0.242]^{* * *}$} & {$[0.241]^{* * *}$} \\
\hline \multirow[t]{2}{*}{ Trade openness } & -0.026 & -0.033 & -0.032 & -0.030 & -0.031 & -0.031 & 0.011 & 0.007 & 0.009 & 0.004 & 0.004 & 0.005 \\
\hline & {$[0.014]^{*}$} & {$[0.015]^{* *}$} & {$[0.015]^{* *}$} & {$[0.015]^{* *}$} & {$[0.015]^{* *}$} & {$[0.015]^{* *}$} & {$[0.043]$} & {$[0.041]$} & {$[0.040]$} & {$[0.041]$} & {$[0.041]$} & {$[0.041]$} \\
\hline \multirow[t]{2}{*}{ Terms of trade growth } & 0.119 & 0.185 & 0.182 & 0.180 & 0.181 & 0.180 & 0.111 & 0.107 & 0.106 & 0.107 & 0.107 & 0.107 \\
\hline & {$[0.068]^{*}$} & {$[0.067]^{* * *}$} & {$[0.067]^{* * *}$} & {$[0.067]^{* * *}$} & {$[0.067]^{* * *}$} & {$[0.067]^{* * *}$} & {$[0.057]^{*}$} & {$[0.056]^{*}$} & {$[0.058]^{*}$} & {$[0.057]^{*}$} & {$[0.057]^{*}$} & {$[0.057]^{*}$} \\
\hline \multirow[t]{2}{*}{ Quality of Institutions } & 0.027 & 0.022 & 0.022 & 0.021 & 0.021 & 0.021 & 0.010 & 0.008 & 0.008 & 0.008 & 0.008 & 0.008 \\
\hline & {$[0.004]^{* * *}$} & {$[0.004]^{* * *}$} & {$[0.004]^{* * *}$} & {$[0.004]^{* * *}$} & {$[0.004]^{* * *}$} & {$[0.004]^{* * *}$} & {$[0.006]^{*}$} & {$[0.005]$} & {$[0.006]$} & {$[0.005]$} & {$[0.005]$} & {$[0.005]$} \\
\hline \multirow[t]{2}{*}{ Overall financial development } & & 0.001 & 0.001 & 0.001 & 0.001 & 0.001 & & 0.002 & 0.001 & 0.002 & 0.002 & 0.002 \\
\hline & & {$[0.000]^{* * *}$} & {$[0.000]^{* * *}$} & {$[0.000]^{* * *}$} & {$[0.000]^{* * *}$} & {$[0.000]^{* * *}$} & & {$[0.001]^{* *}$} & {$[0.001]^{* *}$} & {$[0.001]^{* *}$} & {$[0.001]^{* *}$} & {$[0.001]^{* *}$} \\
\hline \multirow[t]{2}{*}{ Loans by Islamic Banks/GDP } & & & 0.857 & & & & & & 5.254 & & & \\
\hline & & & {$[0.475]^{*}$} & & & & & & {$[2.748]^{*}$} & & & \\
\hline \multirow[t]{2}{*}{ Assets of Islamic Banks/GDP } & & & & 0.673 & & & & & & 0.711 & & \\
\hline & & & & {$[0.202]^{* * *}$} & & & & & & {$[0.269]^{* *}$} & & \\
\hline \multirow[t]{2}{*}{ Deposits of Islamic Banks/GDP } & & & & & 1.001 & & & & & & 0.801 & \\
\hline & & & & & {$[0.233]^{* * *}$} & & & & & & {$[0.279]^{* * *}$} & \\
\hline \multirow{2}{*}{\multicolumn{2}{|c|}{$\begin{array}{l}\text { Composite indicator of Islamic } \\
\text { Banking }\end{array}$}} & & & & & 0.006 & & & & & & 0.008 \\
\hline & & & & & & {$[0.002]^{* * *}$} & & & & & & {$[0.003]^{* *}$} \\
\hline Constant & $\begin{array}{l}-0.024 \\
{[0.030]}\end{array}$ & $\begin{array}{l}0.051 \\
{[0.037]}\end{array}$ & $\begin{array}{l}0.054 \\
{[0.038]}\end{array}$ & $\begin{array}{l}0.059 \\
{[0.038]}\end{array}$ & $\begin{array}{l}0.060 \\
{[0.038]}\end{array}$ & $\begin{array}{l}0.060 \\
{[0.038]}\end{array}$ & $\begin{array}{l}0.172 \\
{[0.201]}\end{array}$ & $\begin{array}{l}0.587 \\
{[0.222]^{* *}}\end{array}$ & $\begin{array}{l}0.628 \\
{[0.232]^{* * * *}}\end{array}$ & $\begin{array}{l}0.584 \\
{[0.218]^{* *}}\end{array}$ & $\begin{array}{l}0.580 \\
{[0.219]^{* *}}\end{array}$ & $\begin{array}{l}0.588 \\
{[0.219]^{* *}}\end{array}$ \\
\hline Observations & 286 & 252 & 252 & 252 & 252 & 252 & 286 & 252 & 252 & 252 & 252 & 252 \\
\hline Number of countries & 52 & 45 & 45 & 45 & 45 & 45 & 52 & 45 & 45 & 45 & 45 & 45 \\
\hline R-squared & 0.34 & 0.33 & 0.33 & 0.34 & 0.34 & 0.34 & 0.32 & 0.37 & 0.38 & 0.37 & 0.37 & 0.38 \\
\hline
\end{tabular}

Note: Robust standard errors in brackets; ${ }^{*}$ significant at $10 \% ;{ }^{* *}$ significant at $5 \%$; *** significant at $1 \%$. 
Regarding the control variables, as expected, accumulation of human capital stimulates economic growth, with the coefficient for primary school enrollment rate highly significant in all regressions. We also tested the secondary school enrollment rate, which gives similar results but missing values on this variable reduce the sample size. Countries with sound macro-economic policies, characterized by low inflation and subdued government current spending, tend to grow faster. This also seems to be the case for countries with positive terms of trade changes and good institutional quality. Further, the hypothesis of economic convergence is supported by the negative and significant sign of the variable initial GDP per capita. In contrast, trade openness seems to have an ambiguous effect on growth, often with a counterintuitive sign, which is not surprising given the contrasting results in previous studies focusing on the growth dividend of trade openness (see Winters, 2004, for an overview). Overall, the model helps explain 33 to 38 percent of the variability in economic growth rates

Although the pooling and fixed effect estimators provide interesting results, the coefficients may be biased in the presence of the endogeneity of the right-hand side variables, in particular with regard to the financial sector indicators. This is particularly relevant for Islamic banking indicators, as their potential endogeneity does not only result from the reverse causality to growth, but also from measurement errors when the full size of Islamic banking development is not captured in the data. $^{10}$

\section{System-GMM}

To address the endogeneity issue, not only for the banking indicators, but also for some other explanatory variables, we rely on the System-GMM estimator (dynamic panel Generalized Methodof-Moment) developed by Blundell and Bond (1998). They show that the System-GMM estimator, which simultaneously uses both the difference in the panel data and the data from the original levels specification, produces dramatic increases in both consistency and efficiency relative to the first-differenced GMM developed by Arellano and Bond (1991). ${ }^{11}$ We use the one-step System GMM estimator while controlling for sample heterogeneity. ${ }^{12}$ Further, to minimize over-fitting of the model, careful attention is paid to the selection of the instruments.

10 Indeed, measurement errors on Islamic banking indicators would be captured by the error term, which will then be correlated with the Islamic banking variable. This violates the assumption of the fixed-effect estimator whereby the error term is orthogonal to right-hand side variables.

11 For a useful guide on the application of the System GMM estimator to growth models, see Bond, Hoeffler and Temple (2001).

12 The two-step method with the Windmeijer's correction produces comparable results. 
For variables considered as predetermined or endogenous, only the first relevant lag is used..$^{13}$ To test the validity of the lagged variables as instruments, we use the standard Hansen test of overidentifying restrictions, where the null hypothesis is that the instrumental variables are not correlated with the residual, and the serial correlation test, where the null hypothesis is that the errors exhibit no second-order serial correlation.

The results from the System GMM estimator presented in Table 2 are comparable to those from the fixed-effect estimator. ${ }^{14}$ Once again, both overall financial system development and Islamic banking development appear to have a meaningful positive impact on economic growth. The coefficients on financial variables should be interpreted with caution, however, given the relatively small size of Islamic banking compared to the overall financial development, which makes them not directly comparable. One way to make the coefficients more informative by taking into account the scale effect is to estimate the coefficients for the standardized financial variables. ${ }^{15}$

The results (in Annex 1) suggest that a one standard deviation increase in the overall financial development would lead to about 3.4 percent increase in real GDP per capita growth. For a one standard deviation increase in the ratio of loans by Islamic banks to GDP, the impact on growth would be of 0.5 percent compared to about 0.8 percent for the ratios of assets and deposits of Islamic banks to GDP. However, even with the standardized variables, the regressions do not allow for reliable inference on the magnitude of the growth impact of Islamic banking, although they provide strong evidence on the positive effect of Islamic banking on growth. From that perspective, the fixed effects and GMM System results are quite encouraging, especially given the concern that a significant number of countries in the sample are reported as not having Islamic banking activities (although they might have banks with Islamic finance windows), while in countries where Islamic banks are present, their relative importance in the economy or the banking system is still far from significant.

13 As commonly done in the literature, we assume that the initial GDP per capita is pre-determined, which rules out contemporaneous correlation with the error term but not feedbacks from past shocks. The variables of inflation, government spending, and more importantly financial sector development and Islamic banking development are treated as endogenous. This allows to address reverse causality issues, measurement errors and omitted variable bias. Given the small size of the sample, not all the variables can be assumed to be endogenous, as the number of instruments grows very quickly to the point that they can weaken the Hansen test. For practical and theoretical reasons, the variables of primary school enrollment, quality of institutions, terms of trade, and trade openness are considered exogenous. Since the first two variables vary little over time, the high persistence makes lagged values poor instruments for the equations in first differences. Although the System GMM is meant to reduce this bias, the use of these instruments leads to a noticeable increase in the Hansen test probability towards the maximum value of 1. For the other two variables, terms of trade and trade openness, we assume that these are likely to be exogenous considering that our sample consists of relatively small and developing countries. All that said, it is worth noting that the quality of the results from the regressions are not affected when all the right-hand side variables are assumed endogenous, except for the Hansen test probability which suffers from the high ratio of the number of instruments over the number of observations.

14 In addition, neither the Hansen test nor the serial correlation test rejects the null hypothesis of the validity of the instruments.

15 The regressions are rerun with the financial variables rescaled to have a mean of zero and a standard deviation of one 
Table 2. Islamic Banking and Growth: Dynamic Panel System GMM estimations

\begin{tabular}{|c|c|c|c|c|c|c|}
\hline & (1) & (2) & (3) & (4) & (5) & (6) \\
\hline \multirow[t]{2}{*}{ Initial GDP per capita } & 0.014 & -0.020 & -0.025 & -0.017 & -0.012 & -0.014 \\
\hline & {$[0.019]^{* * *}$} & {$[0.011]^{* * *}$} & {$[0.011]^{* * *}$} & {$[0.011]^{* * *}$} & {$[0.011]^{* * *}$} & {$[0.011]^{* * *}$} \\
\hline \multirow[t]{2}{*}{ Education } & 0.038 & 0.072 & 0.080 & 0.070 & 0.063 & 0.064 \\
\hline & {$[0.038]$} & {$[0.029]^{* *}$} & {$[0.028]^{* * *}$} & {$[0.029]^{* *}$} & {$[0.030]^{* *}$} & {$[0.030]^{* *}$} \\
\hline \multirow[t]{2}{*}{ Inflation (log) } & -0.235 & -0.213 & -0.219 & -0.208 & -0.203 & -0.203 \\
\hline & {$[0.104]^{* *}$} & {$[0.114]^{*}$} & {$[0.118]^{*}$} & {$[0.107]^{*}$} & {$[0.102]^{* *}$} & {$[0.103]^{* *}$} \\
\hline \multirow[t]{2}{*}{ Government consumption/GDP } & -0.718 & -0.713 & -0.633 & -0.561 & -0.666 & -0.657 \\
\hline & {$[0.468]$} & {$[0.360]^{* *}$} & {$[0.353]^{*}$} & {$[0.312]^{*}$} & {$[0.331]^{* *}$} & {$[0.337]^{*}$} \\
\hline \multirow[t]{2}{*}{ Trade openness } & -0.040 & -0.048 & -0.043 & -0.047 & -0.048 & -0.046 \\
\hline & {$[0.024]^{*}$} & {$[0.023]^{* *}$} & {$[0.024]^{*}$} & {$[0.024]^{*}$} & {$[0.025]^{*}$} & {$[0.024]^{*}$} \\
\hline \multirow[t]{2}{*}{ Terms of trade growth } & 0.108 & 0.167 & 0.175 & 0.162 & 0.158 & 0.159 \\
\hline & {$[0.082]$} & {$[0.078]^{* *}$} & {$[0.079]^{* *}$} & {$[0.078]^{* *}$} & {$[0.079]^{* *}$} & {$[0.077]^{* *}$} \\
\hline \multirow[t]{2}{*}{ Quality of Institutions } & 0.017 & 0.016 & 0.015 & 0.015 & 0.015 & 0.015 \\
\hline & {$[0.007]^{* * *}$} & {$[0.006]^{* * *}$} & {$[0.006]^{* *}$} & {$[0.006]^{* * *}$} & {$[0.005]^{* * *}$} & {$[0.005]^{* * *}$} \\
\hline \multirow[t]{2}{*}{ Overall financial development } & & 0.002 & 0.002 & 0.002 & 0.002 & 0.002 \\
\hline & & {$[0.000]^{* * *}$} & {$[0.000]^{* * *}$} & {$[0.000]^{* * *}$} & {$[0.000]^{* * *}$} & {$[0.000]^{* * *}$} \\
\hline \multirow[t]{2}{*}{ Loans by Islamic Banks/GDP } & & & 1.395 & & & \\
\hline & & & {$[0.518]^{* * *}$} & & & \\
\hline \multirow[t]{2}{*}{ Assets of Islamic Banks/GDP } & & & & 0.900 & & \\
\hline & & & & {$[0.336]^{* * *}$} & & \\
\hline \multirow[t]{2}{*}{ Deposits of Islamic Banks/GDP } & & & & & 1.300 & \\
\hline & & & & & {$[0.522]^{* *}$} & \\
\hline \multirow{3}{*}{$\begin{array}{l}\text { Composite indicator of Islamic } \\
\text { Banking }\end{array}$} & & & & & & 0.007 \\
\hline & & & & & & \\
\hline & & & & & & {$[0.003]^{* *}$} \\
\hline \multirow[t]{2}{*}{ Constant } & 0.027 & 0.169 & 0.188 & 0.140 & 0.127 & 0.134 \\
\hline & {$[0.070]$} & {$[0.062]^{* * *}$} & {$[0.063]^{* * *}$} & {$[0.059]^{* *}$} & {$[0.057]^{* *}$} & {$[0.056]^{* *}$} \\
\hline Observations & 286 & 252 & 252 & 252 & 252 & 252 \\
\hline Number of countries & 52 & 45 & 45 & 45 & 45 & 45 \\
\hline AR2 test prob. & 0.35 & 0.70 & 0.70 & 0.67 & 0.75 & 0.73 \\
\hline Hansen test prob. & 0.07 & 0.36 & 0.64 & 0.67 & 0.67 & 0.76 \\
\hline
\end{tabular}

Note: Robust standard errors in brackets; ${ }^{*}$ significant at $10 \% ;{ }^{* *}$ significant at 5\%; ${ }^{* *}$ significant at $1 \%$. AR(2): Arellano and Bond test of second order autocorrelation 


\section{Robustness analysis and Alternative specifications}

Table 3 presents additional regressions to test the robustness of the relationship between Islamic banking development and economic growth using alternative indicators of Islamic Banking. In column 1 , we use a step dummy taking 1 for strictly positive values of the composite indicator if Islamic banking and zero otherwise to measure the presence of Islamic banking in a given country. The associated coefficient is positive and significant confirming the above results that for countries with similar level of financial development, those with Islamic banking would experience faster economic growth.

Table 3. Dynamic Panel System GMM Estimations with Alternative Indicators of Islamic

Banking Development

\begin{tabular}{|c|c|c|c|c|c|}
\hline & $(1)$ & $(2)$ & (3) & $(4)$ & (5) \\
\hline \multirow[t]{2}{*}{ Initial GDP per capita } & -0.027 & -0.026 & -0.030 & -0.028 & -0.028 \\
\hline & {$[0.012]^{* * *}$} & {$[0.011]^{* * *}$} & {$[0.012]^{* * *}$} & {$[0.012]^{* * *}$} & {$[0.011]^{* * *}$} \\
\hline \multirow[t]{2}{*}{ Education } & 0.087 & 0.088 & 0.089 & 0.085 & 0.089 \\
\hline & {$[0.029]^{* * *}$} & {$[0.027]^{* * *}$} & {$[0.028]^{* * *}$} & {$[0.028]^{* * *}$} & {$[0.027]^{* * *}$} \\
\hline \multirow[t]{2}{*}{ Inflation (log) } & -0.219 & -0.221 & -0.217 & -0.218 & -0.221 \\
\hline & {$[0.117]^{*}$} & {$[0.119]^{*}$} & {$[0.118]^{*}$} & {$[0.116]^{*}$} & {$[0.117]^{*}$} \\
\hline \multirow[t]{2}{*}{ Government consumption/GDP } & -0.683 & -0.610 & -0.298 & -0.667 & -0.615 \\
\hline & {$[0.350]^{*}$} & {$[0.327]^{*}$} & {$[0.277]$} & {$[0.326]^{* *}$} & {$[0.316]^{*}$} \\
\hline \multirow[t]{2}{*}{ Trade openness } & -0.043 & -0.043 & -0.036 & -0.042 & -0.041 \\
\hline & {$[0.023]^{*}$} & {$[0.022]^{* *}$} & {$[0.025]$} & {$[0.024]^{*}$} & {$[0.023]^{*}$} \\
\hline \multirow[t]{2}{*}{ Terms of trade growth } & 0.163 & 0.180 & 0.195 & 0.143 & 0.161 \\
\hline & {$[0.078]^{* *}$} & {$[0.077]^{* *}$} & {$[0.074]^{* * *}$} & {$[0.080]^{*}$} & {$[0.078]^{* *}$} \\
\hline \multirow[t]{2}{*}{ Quality of Institutions } & 0.015 & 0.016 & 0.014 & 0.014 & 0.015 \\
\hline & {$[0.006]^{* *}$} & {$[0.006]^{* * *}$} & {$[0.006]^{* *}$} & {$[0.006]^{* *}$} & {$[0.006]^{* *}$} \\
\hline \multirow[t]{2}{*}{ Overall financial development } & 0.002 & 0.001 & 0.001 & 0.002 & 0.001 \\
\hline & {$[0.000]^{* * *}$} & {$[0.000]^{* * *}$} & {$[0.000]^{* * *}$} & {$[0.000]^{* * *}$} & {$[0.000]^{* * *}$} \\
\hline
\end{tabular}

Dummy variable for strictly positive values of Islamic Banking

Composite indicator of Islamic Banking 0.036

$[0.017]^{* *}$

\begin{tabular}{|c|c|c|c|c|c|}
\hline \multicolumn{6}{|c|}{ Soundness and profitability of Islamic banks } \\
\hline Total capital ratio & & $\begin{array}{l}0.002 \\
{[0.001]^{* * *}}\end{array}$ & & & $\begin{array}{l}0.001 \\
{[0.001]^{*}}\end{array}$ \\
\hline Return on equity & & & $\begin{array}{l}0.004 \\
{[0.001]^{* * *}}\end{array}$ & & \\
\hline Return on assets & & & & $\begin{array}{l}0.026 \\
{[0.012]^{* *}}\end{array}$ & $\begin{array}{l}0.016 \\
{[0.007]^{* *}}\end{array}$ \\
\hline Constant & $\begin{array}{l}0.200 \\
{[0.069]^{* * *}}\end{array}$ & $\begin{array}{l}0.186 \\
{[0.063]^{* * *}}\end{array}$ & $\begin{array}{l}0.167 \\
{[0.063]^{* * *}}\end{array}$ & $\begin{array}{l}0.207 \\
{[0.072]^{* * *}}\end{array}$ & $\begin{array}{l}0.200 \\
{[0.067]^{* * *}}\end{array}$ \\
\hline Observations & 252 & 252 & 252 & 252 & 252 \\
\hline Number of countries & 45 & 45 & 45 & 45 & 45 \\
\hline AR2 test prob. & 0.77 & 0.77 & 0.77 & 0.96 & 0.91 \\
\hline Hansen test prob. & 0.42 & 0.71 & 0.68 & 0.55 & 0.82 \\
\hline
\end{tabular}

Note: Robust standard errors in brackets; ${ }^{*}$ significant at 10\%; ${ }^{* *}$ significant at 5\%; ${ }^{* *}$ significant at $1 \%$. AR(2): Arellano and Bond test of second order autocorrelation 
In the subsequent regressions, we test the impact of variables related to the soundness and profitability of Islamic banks on economic growth (columns 2 to 5). It emerges that well-capitalized Islamic banks may have a favorable impact on economic growth, probably because healthy banks are less prone to crisis. With profitability measured by the standard ratios of Return on Equity (ROE) and Return on Assets (ROA), we find that Islamic banks' profitability also benefit economic growth.

Using alternative measures of overall financial development does not change the conclusion that Islamic banking matters for growth. The coefficient for Islamic banking indicators retains its sign and statistical significance when bank and nonbank private credit ratio, a broader measure of financial development, is controlled for (Table 4, column 1 to 3 ).

Table 4. Use of Different Indicators of Overall Financial Development (System GMM Estimations)

\begin{tabular}{|c|c|c|c|c|c|}
\hline & (1) & (2) & (3) & (4) & (5) \\
\hline \multirow[t]{2}{*}{ Initial GDP per capita } & -0.019 & -0.009 & -0.007 & -0.010 & -0.014 \\
\hline & {$[0.010]^{* * *}$} & {$[0.011]^{* * *}$} & {$[0.011]^{* * *}$} & {$[0.011]^{* * *}$} & {$[0.013]^{* * *}$} \\
\hline \multirow[t]{2}{*}{ Education } & 0.076 & 0.065 & 0.062 & 0.062 & 0.069 \\
\hline & {$[0.029]^{* * *}$} & {$[0.030]^{* *}$} & {$[0.031]^{* *}$} & {$[0.030]^{* *}$} & {$[0.029]^{* *}$} \\
\hline \multirow[t]{2}{*}{ Inflation (log) } & -0.238 & -0.221 & -0.220 & -0.222 & -0.227 \\
\hline & {$[0.134]^{*}$} & {$[0.118]^{*}$} & {$[0.116]^{*}$} & {$[0.098]^{* *}$} & {$[0.122]^{*}$} \\
\hline \multirow[t]{2}{*}{ Government consumption/GDP } & -0.574 & -0.588 & -0.558 & -0.538 & -0.321 \\
\hline & {$[0.267]^{* *}$} & {$[0.245]^{* *}$} & {$[0.242]^{* *}$} & {$[0.263]^{* *}$} & [0.267] \\
\hline \multirow[t]{2}{*}{ Trade openness } & -0.028 & -0.031 & -0.033 & -0.031 & -0.058 \\
\hline & {$[0.021]$} & {$[0.020]$} & {$[0.022]$} & {$[0.020]$} & {$[0.024]^{* *}$} \\
\hline \multirow[t]{2}{*}{ Terms of trade growth } & 0.169 & 0.159 & 0.157 & 0.158 & 0.166 \\
\hline & {$[0.079]^{* *}$} & {$[0.079]^{* *}$} & {$[0.078]^{* *}$} & {$[0.074]^{* *}$} & {$[0.074]^{* *}$} \\
\hline \multirow[t]{2}{*}{ Quality of Institutions } & 0.017 & 0.018 & 0.017 & 0.016 & 0.010 \\
\hline & {$[0.006]^{* * *}$} & {$[0.006]^{* * *}$} & {$[0.005]^{* * *}$} & {$[0.005]^{* * *}$} & {$[0.006]^{*}$} \\
\hline \multirow{2}{*}{$\begin{array}{l}\text { Overall financial development (banks and } \\
\text { nonbanks) }\end{array}$} & 0.001 & 0.001 & 0.001 & & \\
\hline & {$[0.000]^{* *}$} & {$[0.000]^{*}$} & {$[0.000]^{*}$} & & \\
\hline \multirow{2}{*}{$\begin{array}{l}\text { Assets of banks and other financial } \\
\text { institutions/GDP }\end{array}$} & & & & 0.050 & \\
\hline & & & & {$[0.029]^{*}$} & \\
\hline \multirow[t]{2}{*}{ Financial system deposits/GDP } & & & & & 0.134 \\
\hline & & & & & {$[0.037]^{* * *}$} \\
\hline \multirow[t]{2}{*}{ Loans by Islamic Banks/GDP } & 1.593 & & & & \\
\hline & {$[0.683]^{* *}$} & & & & \\
\hline \multirow[t]{2}{*}{ Assets of Islamic Banks/GDP } & & 0.873 & & 1.067 & \\
\hline & & {$[0.373]^{* *}$} & & {$[0.401]^{* * *}$} & \\
\hline \multirow[t]{2}{*}{ Deposits of Islamic Banks/GDP } & & & 1.385 & & 1.507 \\
\hline & & & {$[0.616]^{* *}$} & & {$[0.538]^{* * *}$} \\
\hline \multirow[t]{2}{*}{ Constant } & 0.152 & 0.103 & 0.089 & 0.102 & 0.111 \\
\hline & {$[0.062]^{* *}$} & {$[0.058]^{*}$} & {$[0.055]$} & {$[0.061]^{*}$} & {$[0.065]^{*}$} \\
\hline Observations & 258 & 258 & 258 & 258 & 258 \\
\hline Number of countries & 45 & 45 & 45 & 45 & 45 \\
\hline AR2 test prob. & 0.38 & 0.43 & 0.42 & 0.39 & 0.20 \\
\hline Hansen test prob. & 0.67 & 0.65 & 0.65 & 0.58 & 0.60 \\
\hline
\end{tabular}

Note: Robust standard errors in brackets; ${ }^{*}$ significant at 10\%; ${ }^{* *}$ significant at 5\%; ${ }^{* * *}$ significant at $1 \%$. AR(2): Arellano and Bond test of second order autocorrelation 
In addition, we introduce as a measure of overall financial development the ratio of total financial sector assets to GDP and the ratio of total financial sector deposit to GDP respectively in the specification using the corresponding measure for Islamic banking (Table 4, column 4 and 5). Both the indicators of overall financial development and Islamic banking continue to be positively and significantly correlated with economic growth.

To test the robustness of the results it is worthwhile to assess their sensitivity to sample composition and the time period. As Islamic banks are likely to emerge and expand in countries with large Muslim population, we restricted the sample to countries with more than 50 percent Muslim population share (column 1 to 3 , Table 5). In subsequent regressions, this threshold is increased to 75 percent (column 4 to 6 , Table 5). The results are broadly in line with those obtained for the whole sample and the magnitudes of the coefficients are also comparable, ${ }^{16}$ suggesting that countries with smaller share of Muslim population can potentially benefit from Islamic banking. The regressions are rerun with a sample restricted to net oil importer countries (column 7 to 9 , Table 5) in order to exclude potential outlier countries where Islamic banking development might have been fuelled by oil money. While the three indicators of Islamic banking remain positively correlated with economic growth, the asset and deposit ratios are significant but not the loan ratio. This probably is a reflection that Islamic banks in net oil importer countries may not enjoy the benefits of large oil money deposits that could be used to scale-up loans compared to net oil exporting countries.

We also run the regressions over different time periods to see if the results hold. First, we considered the period 1996-2010, leaving out the first half of the 1990s where Islamic banks were at the nascent stage. Second, we choose to run the regressions over 1990-2007, excluding the 2008-2010 period which might be affected by structural breaks associated with the 2008 global financial crisis. The conclusion that Islamic banking is favorable to economic growth holds regardless of the period considered (Table 6). The regressions over the period 1996-2007 yield similar results.

16 The difference is not statistically significant. We cross-checked this by introducing the interaction between Islamic banking development indicators and the share of Muslims in the population in the baseline model, without any conclusive results. 
Table 5. Sensitivity to Sample Composition (System GMM Estimations)

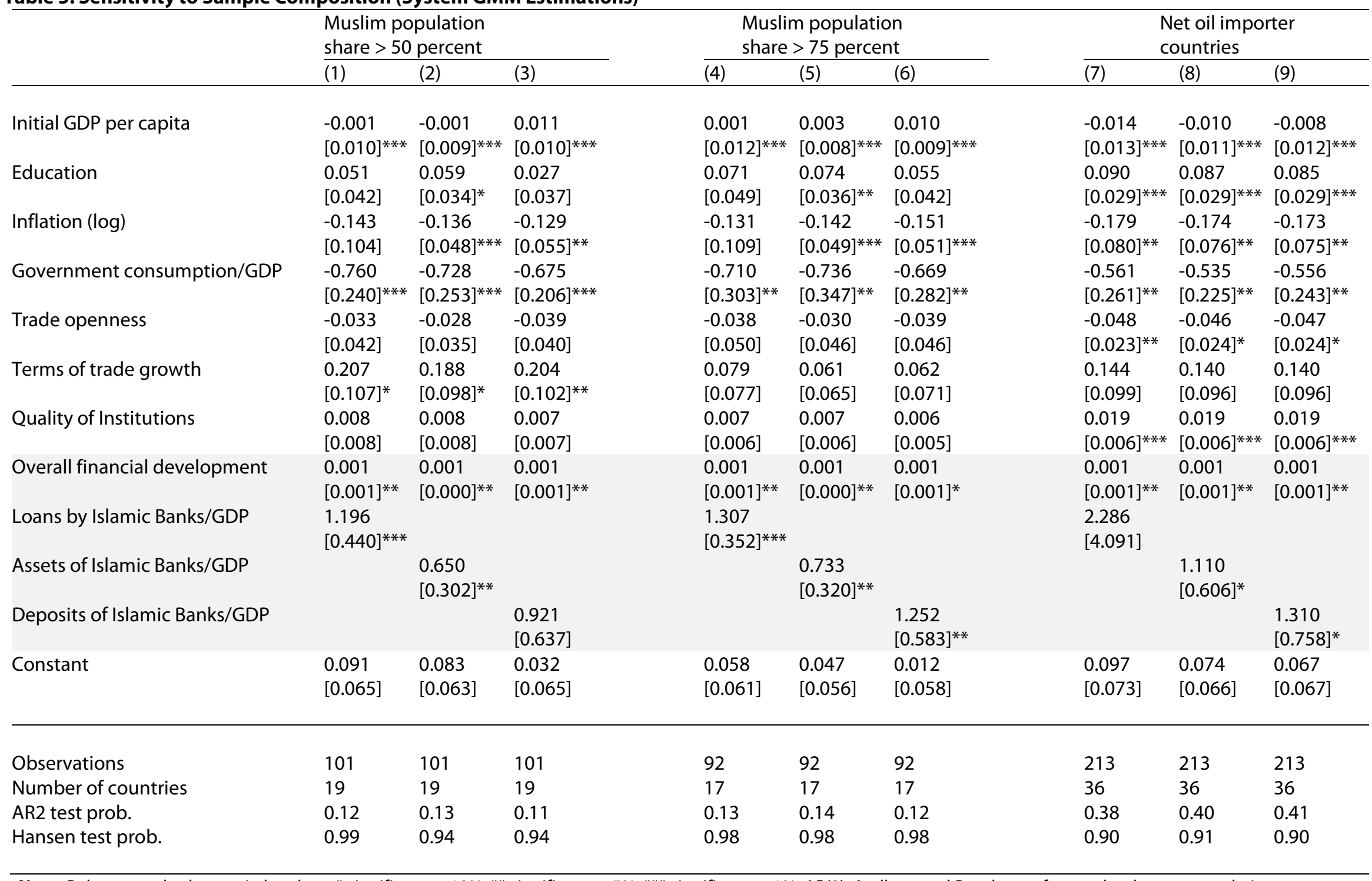

Note: Robust standard errors in brackets; ${ }^{*}$ significant at 10\%; ${ }^{* *}$ significant at 5\%; ${ }^{* *}$ significant at 1\%. AR(2): Arellano and Bond test of second order autocorrelation 
Table 6. Sensitivity to Time Periods (System GMM Estimations)

\begin{tabular}{|c|c|c|c|c|c|c|}
\hline & \multicolumn{3}{|c|}{$\begin{array}{l}1996- \\
2010\end{array}$} & \multicolumn{3}{|c|}{$\begin{array}{l}1990- \\
2007\end{array}$} \\
\hline & $(1)$ & (2) & (3) & (4) & (5) & (6) \\
\hline Initial GDP per capita & $\begin{array}{l}-0.018 \\
{[0.011]^{* * *}}\end{array}$ & $\begin{array}{l}-0.015 \\
{[0.010]^{* * *}}\end{array}$ & $\begin{array}{l}-0.010 \\
{[0.010]^{* * *}}\end{array}$ & $\begin{array}{l}-0.021 \\
{[0.013]^{* * *}}\end{array}$ & $\begin{array}{l}-0.008 \\
{[0.013]^{* * *}}\end{array}$ & $\begin{array}{l}-0.008 \\
{[0.013]^{* * *}}\end{array}$ \\
\hline Education & $\begin{array}{l}0.079 \\
{[0.031]^{* *}}\end{array}$ & $\begin{array}{l}0.078 \\
{[0.028]^{* * *}}\end{array}$ & $\begin{array}{l}0.071 \\
{[0.030]^{* *}}\end{array}$ & $\begin{array}{l}0.071 \\
{[0.025]^{* * *}}\end{array}$ & $\begin{array}{l}0.052 \\
{[0.029]^{*}}\end{array}$ & $\begin{array}{l}0.052 \\
{[0.029]^{*}}\end{array}$ \\
\hline Inflation (log) & $\begin{array}{l}-0.218 \\
{[0.098]^{* *}}\end{array}$ & $\begin{array}{l}-0.191 \\
{[0.081]^{* *}}\end{array}$ & $\begin{array}{l}-0.191 \\
{[0.076]^{* *}}\end{array}$ & $\begin{array}{l}-0.221 \\
{[0.121]^{*}}\end{array}$ & $\begin{array}{l}-0.207 \\
{[0.107]^{*}}\end{array}$ & $\begin{array}{l}-0.207 \\
{[0.107]^{*}}\end{array}$ \\
\hline $\begin{array}{l}\text { Government } \\
\text { consumption/GDP }\end{array}$ & -0.771 & -0.626 & -0.744 & -0.395 & -0.417 & -0.387 \\
\hline & {$[0.369]^{* *}$} & {$[0.328]^{*}$} & {$[0.351]^{* *}$} & [0.332] & [0.305] & [0.304] \\
\hline Trade openness & $\begin{array}{l}-0.046 \\
{[0.025]^{*}}\end{array}$ & $\begin{array}{l}-0.049 \\
{[0.024]^{* *}}\end{array}$ & $\begin{array}{l}-0.052 \\
{[0.026]^{* *}}\end{array}$ & $\begin{array}{l}-0.040 \\
{[0.027]}\end{array}$ & $\begin{array}{l}-0.043 \\
{[0.027]}\end{array}$ & $\begin{array}{l}-0.044 \\
{[0.027]}\end{array}$ \\
\hline Terms of trade growth & $\begin{array}{l}0.255 \\
{[0.072]^{* * *}}\end{array}$ & $\begin{array}{l}0.239 \\
{[0.070]^{* * *}}\end{array}$ & $\begin{array}{l}0.235 \\
{[0.071]^{* * *}}\end{array}$ & $\begin{array}{l}0.172 \\
{[0.079]^{* *}}\end{array}$ & $\begin{array}{l}0.155 \\
{[0.080]^{*}}\end{array}$ & $\begin{array}{l}0.155 \\
{[0.079]^{*}}\end{array}$ \\
\hline Quality of Institutions & $\begin{array}{l}0.023 \\
{[0.007]^{* * *}}\end{array}$ & $\begin{array}{l}0.021 \\
{[0.007]^{* * *}}\end{array}$ & $\begin{array}{l}0.021 \\
{[0.007]^{* * *}}\end{array}$ & $\begin{array}{l}0.014 \\
{[0.007]^{* *}}\end{array}$ & $\begin{array}{l}0.014 \\
{[0.006]^{* *}}\end{array}$ & $\begin{array}{l}0.014 \\
{[0.006]^{* *}}\end{array}$ \\
\hline $\begin{array}{ll}\begin{array}{l}\text { Overall } \\
\text { development }\end{array} & \text { financial }\end{array}$ & 0.002 & 0.002 & 0.002 & 0.001 & 0.001 & 0.001 \\
\hline & {$[0.000]^{* * *}$} & {$[0.000]^{* * *}$} & {$[0.000]^{* * *}$} & {$[0.001]^{* * *}$} & {$[0.000]^{* *}$} & {$[0.000]^{* *}$} \\
\hline Loans by Islamic Banks/GDP & $\begin{array}{l}1.065 \\
{[0.523]^{* *}}\end{array}$ & & & $\begin{array}{l}1.504 \\
{[0.544]^{* * *}}\end{array}$ & & \\
\hline Assets of Islamic Banks/GDP & & $\begin{array}{l}0.868 \\
{[0.371]^{* *}}\end{array}$ & & & $\begin{array}{l}0.923 \\
{[0.349]^{* * *}}\end{array}$ & \\
\hline $\begin{array}{l}\text { Deposits of Islamic } \\
\text { Banks/GDP }\end{array}$ & & & 1.308 & & & 1.482 \\
\hline & & & {$[0.570]^{* *}$} & & & {$[0.573]^{* * *}$} \\
\hline Constant & $\begin{array}{l}0.133 \\
{[0.062]^{* *}}\end{array}$ & $\begin{array}{l}0.103 \\
{[0.062]^{*}}\end{array}$ & $\begin{array}{l}0.093 \\
{[0.061]}\end{array}$ & $\begin{array}{l}0.146 \\
{[0.070]^{* *}}\end{array}$ & $\begin{array}{l}0.085 \\
{[0.067]}\end{array}$ & $\begin{array}{l}0.079 \\
{[0.065]}\end{array}$ \\
\hline Observations & 182 & 182 & 182 & 224 & 224 & 224 \\
\hline Number of countries & 45 & 45 & 45 & 45 & 45 & 45 \\
\hline AR2 test prob. & 0.60 & 0.51 & 0.57 & 0.70 & 0.80 & 0.82 \\
\hline Hansen test prob. & 0.62 & 0.63 & 0.61 & 0.28 & 0.27 & 0.26 \\
\hline
\end{tabular}

Note: Robust standard errors in brackets; ${ }^{*}$ significant at 10\%; ${ }^{* *}$ significant at 5\%; ${ }^{* * *}$ significant at $1 \%$. AR(2): Arellano and Bond test of second order autocorrelation 


\section{ConClusion}

The objective of this paper was to assess the impact of Islamic banking on economic growth. This is the first paper, to our knowledge, that comprehensively assesses this question using robust empirical techniques. We find that, holding constant the level of financial development and other growth determinants, countries where Islamic banking is present and hence its impact on growth is measurable, experience faster economic growth than others. This is a powerful result, and robust to various specifications: we use different measures of Islamic banking development, econometric estimators (pooling, fixed effects and System GMM), and control for country and time-specific dummies. This finding is also encouraging as, despite its rapid growth, Islamic banking still represents a relatively small share of the economy and of the overall size of the financial system, and it has yet to reap the benefits from economies of scale. Although our study does not suggest that Islamic banking provides more "bang for the buck" compared to conventional banks; it does, however, establish the positive impact on growth. As indicated, there are uncertainties on the magnitude of the growth effect of Islamic banking, which calls for further research as Islamic banks diffuse further and become larger. Should future studies confirm this finding, the policy implications would be significant.

As the global crisis has illustrated, conventional banking has many weaknesses-its excessive dependence on leverage being one of them. However, Islamic banking, which is one of the fastest growing segments of global finance, has unique features that are highly appropriate for developing countries. In particular, it is based on risk-sharing, making its activities more closely related to the real economy than conventional finance; it is also more flexible against shocks and more inclusive with regards to growth. Not only does Islamic finance help to stimulate growth, but it also appears less prone to risks such as bubbles (Dridi and Maher, 2011).

This means that many countries that currently suffer from low growth-a feature often present in Muslim countries-may want to further develop this segment of finance. As an initial step, it is essential to develop proper legislation and regulation, as well as the supporting infrastructure, including the necessary skill set. Future areas of research include measuring better Islamic banking development and assessing the impact of Islamic banking on inequality and social development. 


\section{REFERENCES}

Acemoglu, D., S. Johnson, and J. Robinson, 2004, "Institutions as a Fundamental Cause of LongRun Growth," National Bureau of Economic Research Working Paper 10481.

Alesina, A., A. Devleeschauwer, W. Easterly, S. Kurlat, and R. Wacziarg, 2003, "Fractionalization," Journal of Economic Growth, Vol. 8, No. 2, pp. 155-94.

Allen, F. and D. Gale, 2000, Comparing Financial Systems (Boston: MIT Press)

Amin Gutiérrez de Piñeres, S., and M. Ferrantino 2000, Export Dynamics and Economic Growth in Latin America: A Comparative Perspective (UK: Ashgate).

Andersen, T., and F. Tarp (2003), "Financial Liberalization, Financial Development and Economic Growth in LDCs", Journal of International Development 15(2), pp. 189-209.

Arcand, J.-L., E. Berkes and U. Panizza (2012), “Too Much Finance?”, IMF Working

Paper No. 12/161.

Arellano, M. and S. Bond, 1991, "Some Tests of Specification for Panel Data: Monte Carlo Evidence and an Application to Employment Equations," Review of Economic Studies, Vol. 58, pp. 277-297.

Arellano, M. and O. Bover, 1995, "Another Look at the Instrumental-Variable Estimation of ErrorComponents Models," Journal of Econometrics, Vol. 68, No. 1, pp. 29-52.

Beck, T., A. Demirguc-Kunt and R. Levine, 2000, "A New Database on Financial Development and Structure," World Bank Economic Review, No 14, pp.597-605

Beck, T., A. Demirguc-Kunt and O. Merrouche, 2010, "Islamic vs. conventional banking : business model, efficiency and stability," World Bank Working Paper No.5,446

Benhabib, J. and M. Spiegel, 1994. "The role of human capital in economic development: evidence from aggregate cross-country data," Journal of Monetary Economics Vol. 34, pp. 143-174.

Blundell, R., and S. Bond, 1998, "Initial Conditions and Moment Restrictions in Dynamic Panel Data Models," Journal of Econometrics, Vol. 87, No. 1, pp. 115-43.

Bond, S., A. Hoeffler, and J. Temple, 2001, "GMM Estimation of Empirical Growth Models," Economics Papers 2001-W21 (Oxford: Economics Group, Nuffield College, University of Oxford).

Cleveland, W. S, 1979, "Robust Locally Weighted Regression and Smoothing Scatterplots," Journal of the American Statistical Association, 74, pp. 829-836.

Demirguc-Kunt, A. and R. Levine, 2009, "Finance and Inequality: Theory and Evidence," NBER Working Paper No. 15275.

Demirguc-Kunt, A., L. Klapper and D. Randall, YEAR?, "Islamic Finance and Financial Inclusion: Measuring Use of and Demand for Formal Financial Services among Muslim Adults," World Bank Policy Research Paper No. 6642 
DiNardo, J and J. L. Tobias, 2001, "Nonparametric Density and Regression Estimation," Journal of Economic Perspectives, American Economic Association, vol. 15(4), pp.11-28.

Easterly, W., and A. Kraay, 2000, "Small States, Small Problems? Income, Growth, and Volatility in Small States," World Development Vol.28, pp.2013-27.

Easterly, W. and A. Reshef, 2009, "Big Hits in Manufacturing Exports and Development," NYU Working Paper mimeo.

Gewal, B., 2013, "Overview of the Islamic Financial Landscape: Globally and in Europe," Kuwait Finance House mimeo

Greenwood, J. and B. Jovanovic, 1990. "Financial Development, Growth, and the Distribution of Income," Journal of Political Economy, Vol. 98(5), pp. 1076-1107.

Guillaumont Jeanneney, S. and K. Kpodar, 2006, "Développement financier, instabilité financière et croissance économique," Économie et Prévision, Vol. 174 (3), pp.87-111.

Gurley, J.G. and E.S. Shaw, (1960), Money in a Theory of Finance, (Washington D.C.: The Brookings Institution).

Hassan, M. and J. Dridi, 2010, "The Effects of the Global Crisis on Islamic and Conventional Banks: A Comparative Study," IMF Working Paper No. 201

Honohan, P., 2001 "Islamic Financial Intermediation: Economic and Prudential Considerations," Development Research Group and Financial Sector Strategy Department mimeo, (Washington DC: World Bank)

Ichimura, H. and P. Todd, 2007, "Implementing Nonparametric and Semiparametric Estimators," Handbook of Econometrics, J.J. Heckman \& E.E. Leamer (ed.), Vol. 6, Chap. 74.

Imam, P. and K. Kpodar, 2013, "Islamic Banking: How has it Expanded?" Emerging Markets Finance and Trade, Vol. 49, pp. 112-137

Jansen, M. (2004), "Income Volatility in Small and Developing Economies: Export Concentration Matters," Discussion Paper 3. World Trade Organization, Geneva.

King R. and R. Levine (1993a) "Finance and Growth: Schumpeter Might Be Right," Quarterly Journal of Economics, Vol. 108, pp. 717-738.

(1993b) "Finance, Entrepreneurship, and Growth: Theory and Evidence," Journal of Monetary Economics, Vol. 32, pp. 513-542.

(1993c) "Financial Intermediation and Economic Development," in Financial Intermediation in the Construction of Europe, Eds: Mayer C. and Vives X., London: Centre for Economic Policy Research, pp. 156-189.

Levine, R., 1997, "Financial Development and Economic Growth: Views and Agenda," Journal of Economic Literature, Vol. 35, No. 3, pp. 688-726.

Levine R., N. Loayza and T. Beck, 2000, "Financial Intermediation and Growth: Causality and Causes," Journal of Monetary Economics, Vol. 46, no. 1, August, pp. 31-77. 
Levine R., 2002, "Bank-based or Market-based Financial Systems: Which is Better?" NBER Working Paperno. 9138.

2005, "Finance and Growth: Theory and Evidence" pp. 865-934 in Aghion, Philippe and Steven Durlauf, "Handbook of Economic Growth, Vol.1a (Amsterdam: North-Holland Elsevier)

McKinnon R. I., 1973, "Money and Capital in Economic Development," (Washington D.C.: The Brooking Institution).

Modigliani, F and M. Miller, 1958 "The Cost of Capital, Corporation Finance and the Theory of Investment". American Economic Review, Vol.48, pp. 261-297

Moody's, 2009, 'The Liquidity/Leverage Trade-Off for Islamic Banks-and its Impact on Their Ratings" (Moody's Investors Service)

Nolan, M., 2003, "Religion, Culture, and Economic Performance" Peterson Institute Working Paper Series WP03-8, Peterson Institute for International Economics

Panizza, U., 2014, "Financial Development and Economic Growth: Known Knowns, Known Unknowns, and Unknown Unknowns," Revue d'économie du développement, Vol. 22(2), pp. 33-66.

Pritchett, L., 1997, "Where Has All the Education Gone?" Working Paper No. 1581 (Washington D.C: World Bank).

Rajan, R. and L. Zingales, 1998. "Financial Dependence and Growth," American Economic Review, Vol. 88(3), pp. 559-86.

Robinson, J., 1952, "The Generalization of the General Theory," in The Rate of Interest and Other Essays, (London: Macmillan).

Schumpeter J., 1912, "The Theory of Economic Development," (Leipzig: Dunker \& Humblot, translated by Redvers Opie, Cambridge, MA: Harvard University Press, 1934).

Winters, A., 2004, "Trade Liberalisation and Economic Performance: An Overview," Economic Journal, Vol. 114, pp. 4-21. 
Islamic Banking and Growth: Dynamic Panel System GMM estimations with Standardized Coefficients for the Financial Variables

\begin{tabular}{|c|c|c|c|c|}
\hline & $(1)$ & $(2)$ & (3) & $(4)$ \\
\hline Initial GDP per capita & $\begin{array}{l}-0.025 \\
{[0.011]^{* * *}}\end{array}$ & $\begin{array}{l}-0.016 \\
{[0.011]^{* * *}}\end{array}$ & $\begin{array}{l}-0.011 \\
{[0.011]^{* * *}}\end{array}$ & $\begin{array}{l}-0.018 \\
{[0.011]^{* * *}}\end{array}$ \\
\hline Education & $\begin{array}{l}0.079 \\
{[0.029]^{* * *}}\end{array}$ & $\begin{array}{l}0.068 \\
{[0.029]^{* *}}\end{array}$ & $\begin{array}{l}0.061 \\
{[0.031]^{* *}}\end{array}$ & $\begin{array}{l}0.070 \\
{[0.028]^{* *}}\end{array}$ \\
\hline Inflation (log) & $\begin{array}{l}-0.218 \\
{[0.118]^{*}}\end{array}$ & $\begin{array}{l}-0.204 \\
{[0.105]^{*}}\end{array}$ & $\begin{array}{l}-0.199 \\
{[0.100]^{* *}}\end{array}$ & $\begin{array}{l}-0.189 \\
{[0.090]^{* *}}\end{array}$ \\
\hline Government consumption/GDP & $\begin{array}{l}-0.641 \\
{[0.354]^{*}}\end{array}$ & $\begin{array}{l}-0.581 \\
{[0.318]^{*}}\end{array}$ & $\begin{array}{l}-0.681 \\
{[0.339]^{* *}}\end{array}$ & $\begin{array}{l}-0.491 \\
{[0.286]^{*}}\end{array}$ \\
\hline Trade openness & $\begin{array}{l}-0.043 \\
{[0.024]^{*}}\end{array}$ & $\begin{array}{l}-0.046 \\
{[0.024]^{* *}}\end{array}$ & $\begin{array}{l}-0.048 \\
{[0.024]^{* *}}\end{array}$ & $\begin{array}{l}-0.051 \\
{[0.025]^{* *}}\end{array}$ \\
\hline Terms of trade growth & $\begin{array}{l}0.174 \\
{[0.077]^{* *}}\end{array}$ & $\begin{array}{l}0.159 \\
{[0.077]^{* *}}\end{array}$ & $\begin{array}{l}0.155 \\
{[0.078]^{* *}}\end{array}$ & $\begin{array}{l}0.172 \\
{[0.075]^{* *}}\end{array}$ \\
\hline Quality of Institutions & $\begin{array}{l}0.016 \\
{[0.006]^{* *}}\end{array}$ & $\begin{array}{l}0.015 \\
{[0.006]^{* * *}}\end{array}$ & $\begin{array}{l}0.015 \\
{[0.005]^{* * *}}\end{array}$ & $\begin{array}{l}0.015 \\
{[0.006]^{* * *}}\end{array}$ \\
\hline \multicolumn{5}{|l|}{ Standardized coefficients } \\
\hline Overall financial development & $\begin{array}{l}0.034 \\
{[0.009]^{* * *}}\end{array}$ & $\begin{array}{l}0.032 \\
{[0.008]^{* * *}}\end{array}$ & $\begin{array}{l}0.032 \\
{[0.009]^{* * *}}\end{array}$ & $\begin{array}{l}0.034 \\
{[0.008]^{* * *}}\end{array}$ \\
\hline Loans by Islamic Banks/GDP & $\begin{array}{l}0.005 \\
{[0.002]^{* * *}}\end{array}$ & & & \\
\hline Assets of Islamic Banks/GDP & & $\begin{array}{l}0.008 \\
{[0.003]^{* * *}}\end{array}$ & & \\
\hline Deposits of Islamic Banks/GDP & & & $\begin{array}{l}0.008 \\
{[0.003]^{* *}}\end{array}$ & \\
\hline Composite indicator of Islamic Banking & & & & $\begin{array}{l}0.007 \\
{[0.003]^{* * *}}\end{array}$ \\
\hline Constant & $\begin{array}{l}0.223 \\
{[0.067]^{* * *}}\end{array}$ & $\begin{array}{l}0.171 \\
{[0.062]^{* * *}}\end{array}$ & $\begin{array}{l}0.160 \\
{[0.059]^{* * *}}\end{array}$ & $\begin{array}{l}0.171 \\
{[0.067]^{* *}}\end{array}$ \\
\hline Observations & 252 & 252 & 252 & 252 \\
\hline Number of countries & 45 & 45 & 45 & 45 \\
\hline AR2 test prob. & 0.70 & 0.69 & 0.75 & 0.63 \\
\hline Hansen test prob. & 0.73 & 0.74 & 0.76 & 0.63 \\
\hline
\end{tabular}

Note: Robust standard errors in brackets; ${ }^{*}$ significant at $10 \%$; ${ }^{* *}$ significant at $5 \%$; ** significant at 1\%. AR(2): Arellano and Bond test of second order autocorrelation 


\section{APPENDIX TABLES}

\section{Appendix Table 1. Variable Definition and Sources}

\begin{tabular}{|c|c|c|}
\hline Variables & Definitions & Sources \\
\hline GDP per capita growth & $\begin{array}{l}\text { Change in the ratio of real Gross Domestic } \\
\text { Product (GDP) divided by the size of the } \\
\text { population. }\end{array}$ & \\
\hline Inflation (log) & Change in consumer price index (CPI). & \\
\hline Government consumption/GDP & $\begin{array}{l}\text { General government current expenditure } \\
\text { divided by GDP. }\end{array}$ & International Monetary Fund \\
\hline Terms of trade growth & $\begin{array}{l}\text { Change in terms of trade index calculated as } \\
\text { the percentage ratio of the export unit value } \\
\text { indexes to the import unit value indexes, } \\
\text { measured relative to the base year } 2000 \text {. }\end{array}$ & \\
\hline Education (primary) & $\begin{array}{l}\text { The ratio of total enrollment in primary } \\
\text { education, regardless of age, to the population } \\
\text { of the age group that officially corresponds to } \\
\text { the primary education level. }\end{array}$ & $\begin{array}{l}\text { World Bank (Word Development } \\
\text { Indicators) }\end{array}$ \\
\hline Trade openness & $\begin{array}{l}\text { The sum of exports and imports of goods and } \\
\text { services measured as a share of GDP. }\end{array}$ & \\
\hline Rule of law & $\begin{array}{l}\text { The confidence of citizens in law, and the } \\
\text { extent that they abide by the rules of the } \\
\text { society, such as contract enforcement, } \\
\text { property rights, police, and court. }\end{array}$ & $\begin{array}{l}\text { World Bank (World Bank } \\
\text { Governance Indicators) }\end{array}$ \\
\hline $\begin{array}{l}\text { Overall financial development } \\
\text { (Bank private credit ratio) }\end{array}$ & $\begin{array}{l}\text { Credit by deposit money banks to the private } \\
\text { sector divided by GDP. }\end{array}$ & \\
\hline $\begin{array}{l}\text { Private credit by banks and other } \\
\text { financial institutions/GDP }\end{array}$ & $\begin{array}{l}\text { Demand, time and saving deposits in deposit } \\
\text { money banks and other financial institutions } \\
\text { as a share of GDP }\end{array}$ & $\begin{array}{l}\text { Beck, Demirgüç-Kunt and Levine } \\
\text { (2000); } 2013 \text { Financial }\end{array}$ \\
\hline $\begin{array}{l}\text { Assets of banks and other financial } \\
\text { institutions/GDP }\end{array}$ & $\begin{array}{l}\text { Credit by deposit money banks and other } \\
\text { financial institutions to the private sector as a } \\
\text { percentage of GDP }\end{array}$ & Development and Structure Dataset \\
\hline Financial system deposits/GDP & $\begin{array}{l}\text { Claims on domestic real nonfinancial sector } \\
\text { by deposit money banks and other financial } \\
\text { institutions as a share of GDP }\end{array}$ & \\
\hline Share of Muslims in the population & $\begin{array}{l}\text { Numbers of muslims divided by the size of the } \\
\text { population. }\end{array}$ & Alesina, et al. (2003) \\
\hline Loans by Islamic Banks/GDP & Total loans by Islamic Banks divided by GDP & \\
\hline Assets of Islamic Banks/GDP & Total assets of Islamic Banks divided by GDP & \\
\hline Deposits in Islamic Banks/GDP & $\begin{array}{l}\text { Total deposits in Islamic Banks divided by } \\
\text { GDP }\end{array}$ & \\
\hline Capital ratio of Islamic banks & $\begin{array}{l}\text { Capital of Islamic banks as of share of their } \\
\text { total assets }\end{array}$ & Bankscope database \\
\hline Return on equity of Islamic banks & $\begin{array}{l}\text { Net income of Islamic Banks as a percentage of } \\
\text { shareholders equity }\end{array}$ & \\
\hline Return on assets of Islamic banks & $\begin{array}{l}\text { Net income of Islamic Banks as a percentage of } \\
\text { their assets }\end{array}$ & \\
\hline
\end{tabular}


Appendix Table 2. Correlation Matrix

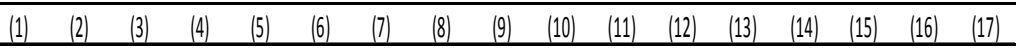

GDP per capita growth
Education (primary)
Inflation (log)
Government consumption/GDP
Trade openness
Terms of trade growth
Rulle of law
Overall financial development (Bank private credit ratio)
Loans by Islamic Banks/GDP
Assets of Islamic Banks/GDP
Deposits in Islamic Banks/GDP
Capital ratio of Islamic banks
Return on equity of Islamic banks
Return on assets of Islamic banks
Private credit by banks and other financial institutions/GDP
Assets of banks and other financial institutions/GDP
Financial system deposits/GDP

(1) 1.00

(2) $0.21 \quad 1.00$

(3) $\quad \begin{array}{rrr}-0.35 & -0.07 & 1.00\end{array}$

(4) $\quad \begin{array}{rrrr}-0.06 & 0.06 & -0.10 & 1.00\end{array}$

(5) $\quad \begin{array}{lllll}0.04 & 0.29 & -0.14 & 0.22 & 1.00\end{array}$

(6) $\quad \begin{array}{llllll}0.15 & 0.06 & -0.08 & -0.02 & 0.12 & 1.00\end{array}$

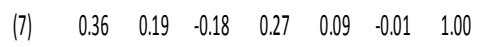

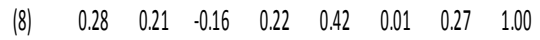

(9) $\quad \begin{array}{lllllllll}0.10 & 0.04 & 0.00 & 0.03 & -0.02 & 0.06 & 0.12 & 0.10 & 1.00\end{array}$

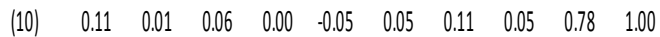

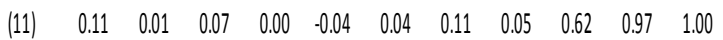

$\begin{array}{lllllllllllll}\text { (12) } & 0.16 & 0.03 & -0.05 & 0.10 & 0.19 & -0.01 & 0.14 & 0.35 & 0.43 & 0.36 & 0.29 & 1.00\end{array}$

$\begin{array}{llllllllllllll}(13) & 0.22 & 0.03 & -0.02 & -0.12 & -0.03 & -0.05 & 0.07 & 0.22 & 0.39 & 0.36 & 0.31 & 0.56 & 1.00\end{array}$

$\begin{array}{lllllllllllllll}\text { (14) } & 0.12 & 0.05 & -0.01 & 0.12 & 0.03 & 0.10 & 0.16 & 0.18 & 0.48 & 0.41 & 0.35 & 0.27 & 0.24 & 1.00\end{array}$

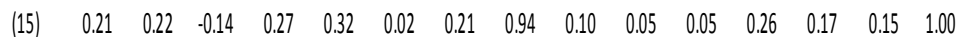

(16) $\quad \begin{array}{llllllllllllllll}0.20 & 0.23 & -0.14 & 0.27 & 0.26 & 0.04 & 0.21 & 0.90 & 0.07 & 0.03 & 0.03 & 0.25 & 0.17 & 0.13 & 0.97 & 1.00\end{array}$

$\begin{array}{llllllllllllllllll}\text { (17) } & 0.29 & 0.25 & -0.16 & 0.20 & 0.40 & 0.06 & 0.34 & 0.89 & 0.13 & 0.08 & 0.07 & 0.41 & 0.26 & 0.17 & 0.79 & 0.83 & 1.00\end{array}$

\section{Appendix Table 3. Summary Statistics}

\begin{tabular}{|c|c|c|c|c|c|}
\hline Variables & Observations & Mean & Std. Dev. & Min & $\operatorname{Max}$ \\
\hline GDP per capita growth & 286 & 0.05 & 0.09 & -0.39 & 0.33 \\
\hline Education (primary) & 286 & 0.93 & 0.24 & 0.26 & 1.56 \\
\hline Inflation (log) & 286 & 0.13 & 0.35 & -0.05 & 4.48 \\
\hline Government consumption/GDP & 286 & 0.14 & 0.05 & 0.04 & 0.41 \\
\hline Trade openness & 286 & 0.71 & 0.35 & 0.14 & 2.14 \\
\hline Terms of trade growth & 286 & 0.00 & 0.07 & -0.37 & 0.28 \\
\hline Rule of law & 286 & 3.23 & 1.13 & 0.14 & 6.00 \\
\hline Overall financial development (Bank private credit ratio) & 252 & 23.1 & 21.5 & 0.4 & 103.8 \\
\hline Loans by Islamic Banks/GDP & 286 & 0.001 & 0.005 & 0.000 & 0.051 \\
\hline Assets of Islamic Banks/GDP & 286 & 0.002 & 0.011 & 0.000 & 0.125 \\
\hline Deposits in Islamic Banks/GDP & 286 & 0.001 & 0.008 & 0.000 & 0.106 \\
\hline Capital ratio of Islamic banks & 286 & 2.18 & 8.15 & 0.00 & 66.17 \\
\hline Return on equity of Islamic banks & 286 & 1.59 & 5.71 & -13.06 & 47.12 \\
\hline Return on assets of Islamic banks & 286 & 0.10 & 0.64 & -4.07 & 3.34 \\
\hline Private credit by banks and other financial institutions/GDP & 286 & 28.1 & 30.7 & 0.4 & 168.2 \\
\hline Assets of banks and other financial institutions/GDP & 286 & 0.34 & 0.35 & 0.00 & 2.08 \\
\hline Financial system deposits/GDP & 286 & 0.32 & 0.25 & 0.01 & 1.15 \\
\hline
\end{tabular}


Appendix Table 4. Country Sample

\begin{tabular}{|c|c|c|c|}
\hline DZA & Algeria* & MWI & Malawi \\
\hline AGO & Angola & MYS & Malaysia* \\
\hline BGD & Bangladesh* & MLI & Mali* \\
\hline BWA & Botswana & MNG & Mongolia \\
\hline BFA & Burkina Faso* & MAR & Morocco* \\
\hline CMR & Cameroon* & MOZ & Mozambique* \\
\hline $\mathrm{CHN}$ & China & NAM & Namibia \\
\hline ZAR & Congo, Dem. Rep. & NER & Niger* \\
\hline COG & Congo, Rep. & PAK & Pakistan* \\
\hline CIV & Côte d'Ivoire* & PNG & Papua New Guinea \\
\hline EGY & Egypt, Arab Rep.* & PHL & Philippines \\
\hline ETH & Ethiopia & SEN & Senegal* \\
\hline GAB & Gabon* & ZAF & South Africa \\
\hline GMB & Gambia, The* & LKA & Sri Lanka \\
\hline GHA & Ghana & SDN & Sudan* \\
\hline GIN & Guinea* & SYR & Syrian Arab Republic* \\
\hline GNB & Guinea-Bissau* & TZA & Tanzania \\
\hline IND & India & THA & Thailand \\
\hline IDN & Indonesia* & TGO & Togo* \\
\hline IRN & Iran, Islamic Rep.* & TUN & Tunisia* \\
\hline JOR & Jordan* & TUR & Turkey* \\
\hline KEN & Kenya & UGA & Uganda* \\
\hline LBN & Lebanon* & VNM & Vietnam \\
\hline LBR & Liberia & YEM & Yemen, Rep.* \\
\hline LBY & Libya* & $\mathrm{ZMB}$ & Zambia \\
\hline MDG & Madagascar & ZWE & Zimbabwe \\
\hline
\end{tabular}

Note: * Organization of Islamic States (OIS) members 
"Sur quoi la fondera-t-il l'économie du monde qu'il veut gouverner? Sera-ce sur le caprice de chaque particulier? Quelle confusion! Sera-ce sur la justice? Il l'ignore."

Pascal

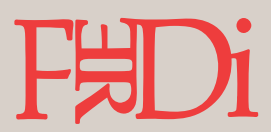

Created in 2003, the Fondation pour les études et recherches sur le développement international aims to promote a fuller understanding of international economic development and the factors that influence it.

\section{$\hookrightarrow$ Contact}

www.ferdi.fr

contact@ferdi.fr

+33 (o)4 73177530 